\title{
Effect of Inhibition of Colony-Stimulating Factor 1 Receptor on Choroidal Neovascularization in Mice
}

\author{
Petra Schwarzer, Despina Kokona, Andreas Ebneter, and Martin S. Zinkernagel
}

From the Department of Ophthalmology, Inselspital, Bern University Hospital, University of Bern, Bern; and the Department for BioMedical Research, University of Bern, Bern, Switzerland

Accepted for publication

October 21, 2019.

Address correspondence to Martin S. Zinkernagel, M.D., Ph.D., Department of Ophthalmology, Inselspital, Universität Bern, 3010 Bern, Switzer-

land. E-mail: martin.

zinkernagel@insel.ch.

\begin{abstract}
Neovascular age-related macular degeneration is one of the leading causes of blindness. Microglia and macrophages play a critical role in choroidal neovascularization (CNV) and may, therefore, be potential targets to modulate the disease course. This study evaluated the effect of the colony-stimulating factor1 receptor inhibitor PLX5622 on experimental laser-induced CNV. A 98\% reduction of retinal microglia cells was observed in the retina 1 week after initiation of PLX5622 treatment, preventing accumulation of macrophages within the laser site and leading to a reduction of leukocytes within the choroid after CNV induction. Mice treated with PLX5622 had a significantly faster decrease of the CNV lesion size, as revealed by in vivo imaging and immunohistochemistry from day 3 to day 14 compared with untreated mice. Several inflammatory modulators, such as chemokine (C-C motif) ligand 9, granulocytemacrophage colony-stimulating factor, soluble tumor necrosis factor receptor-I, IL- $1 \alpha$, and matrix metallopeptidase-2, were elevated in the acute phase of the disease when microglia were ablated with PLX5622, whereas other cytokines (eg, interferon- $\gamma, \mathrm{IL}-4$, and IL-10) were reduced. Our results suggest that colony-stimulating factor-1 receptor inhibition may be a novel therapeutic target in patients with neovascular age-related macular degeneration. (Am J Pathol 2020, 190: 412-425; https://doi.org/ 10.1016/j.ajpath.2019.10.011)
\end{abstract}

The main feature of choroidal neovascularization (CNV) is new abnormal blood vessels emerging from the choroid and growing through the Bruch membrane and sometimes the retinal pigment epithelium (RPE). CNV is observed during neovascular age-related macular degeneration (AMD) and can lead to vision loss in patients experiencing AMD. ${ }^{1,2}$ Although the particular pathogenesis of AMD remains unknown, there are several previous studies showing the involvement of the innate immune system in the development of the disease. ${ }^{3-5}$

Microglia, residing in the retina, are dynamic surveillants of the extracellular environment, ${ }^{6}$ located mainly in the ganglion cell layer, the inner nuclear layer, and the outer plexiform and nuclear layers. They can become reactive on injury and acquire migration and proliferation capabilities. ${ }^{7}$ Several studies have suggested that along with resident microglia, infiltrating macrophages may also play a prominent role in the pathogenesis of AMD. ${ }^{8-11}$ In AMD, microglia/macrophages have been found in the subretinal space, where they are associated with drusen accumulation and $\mathrm{CNV}^{12}$ In experimental laser-induced CNV, macrophage depletion, using clodronate liposomes, resulted in reduced $\mathrm{CNV}$ size ${ }^{13,14}$; and other studies have shown that the $\mathrm{CNV}$ area is significantly reduced in mice knocked out for the $\mathrm{C}-\mathrm{C}$ chemokine receptor type 2 ( $\mathrm{Ccr} 2)$, a crucial

Supported by Swiss RetinAward grants (P.S. in 2017; D.K. in 2016), supported by the Swiss VitreoRetinal Group in cooperation with Bayer AG.

P.S. and D.K. contributed equally to this work.

Disclosures: PLX5622 chow was provided by Plexxikon Inc. (Berkeley, CA) under a Materials Transfer Agreement; P.S. and D.K. received grant support from Bayer; A.E. received honoraria from Bayer for lectures and nonfinancial support from Allergan and Novartis; M.S.Z. received financial support from Allergan, Bayer, Heidelberg Engineering, and Novartis and equity from Novartis. 
component mediating macrophage infiltration. ${ }^{15}$ CCR2 as well as the $\mathrm{CX} 3 \mathrm{C}$ chemokine receptor 1 are considered important factors for recruitment of macrophages to areas of inflammation and for the trafficking and the cellular migration of microglia into the subretinal space. ${ }^{12}$ There is increasing evidence for their role in AMD development as lower expression of $\mathrm{CX} 3 \mathrm{C}$ chemokine receptor 1 has been observed in patients with AMD. ${ }^{16}$

The involvement of microglia/macrophages in CNV is further supported by studies showing that reduction of immune cells' reactivity by intravitreal injections of polysialic acid leads to reduced vascular leakage in a laserinduced CNV mouse model. ${ }^{17,18}$ Moreover, loss of interferon- $\beta$ and transforming growth factor- $\beta$ signaling in retinal microglia has been implicated in increased microglia reactivity and exacerbated CNV lesions in mice, ${ }^{19,20}$ supporting a role of microglia cytokine signaling in the course of CNV.

Microglia depletion has been proved useful for the investigation of their involvement in several central nervous system disease paradigms, ${ }^{21,22}$ and it has been recently shown that brain microglia can be effectively eliminated by colony-stimulating factor-1 receptor (CSF1R) inhibition. ${ }^{23,24}$ This was also observed in the retina, where microglia cells were eliminated by $92 \%$ to $97 \%$ in mice kept on a CSF-1R inhibitor-supplied diet for 1 week, ${ }^{25,26}$ whereas immune cells in the spleen and the bone marrow were not affected after 1 to 3 weeks of PLX5622 treatment. ${ }^{27-29}$ However, PLX5622-dependent reduction of antigen-presenting cells in the blood has been reported. ${ }^{29}$ Cessation of CSF-1R inhibitor resulted in repopulation of retinal microglia from the remaining resident microglia pool in a $\mathrm{CX} 3 \mathrm{C}$ chemokine receptor 1 -dependent manner. ${ }^{30,31}$ However, more recent studies using bone marrow chimera mice suggest that monocytederived macrophages repopulate the retina, after cessation of PLX5622 treatment, where they adopt a ramified microglia-like morphology. ${ }^{32}$ Herein, the CSF-1R inhibitor PLX5622 was used during the whole duration of the experiments to gain insight in the role of retinal microglia/ macrophages on the course of experimental laser-induced CNV.

\section{Materials and Methods}

\section{Animals}

This study was approved by the local Animal Ethics Committee (Veterinärdienst des Kantons Bern: BE 136/16) and conformed to the Association for Research in Vision and Ophthalmology Statement for the Use of Animals in Ophthalmic and Vision Research. Female mice were used, on the basis of the observation that female mice are more prone to $\mathrm{CNV}$ formation. ${ }^{33} \mathrm{C} 57 \mathrm{BL} / 6 \mathrm{~J}$ mice (Charles River Laboratories, Sulzfeld, Germany) and MacGreen
[B6N.Cg-Tg(Csf1r-EGFP)1Hume/J $]^{34}$ heterozygous female mice (6 to 8 weeks old) were employed.

Mice had ad libitum access to PLX5622-containing chow (1200 parts per million formulated in AIN-76A standard rodent diet; Research Diets, Inc., New Brunswick, NJ) or AIN-76A standard rodent diet (control chow). Animals were housed, in groups of two to five, under temperature- and humidity-controlled conditions in individually ventilated cages with a 12-hour light/12-hour dark cycle. Before laser treatment or imaging, mice were anesthetized with $1 \mathrm{mg} / \mathrm{kg}$ medetomidine (Dormitor, $1 \mathrm{mg} / \mathrm{mL}$; Provet AG, Lyssach, Switzerland) and $80 \mathrm{mg} / \mathrm{kg}$ ketamine (Ketalar, $50 \mathrm{mg} / \mathrm{mL}$; Parke-Davis, Zurich, Switzerland), as previously described. ${ }^{25}$ At the end of the intervention, medetomidine was antagonized by injection of $2.25 \mathrm{mg} / \mathrm{kg}$ atipamezole (Antisedan, $5 \mathrm{mg} / \mathrm{mL}$; Provet AG). Before and 1 week after the initiation of the PLX5622 diet, as well as at days 3, 7, and 14 after laser treatment, mouse retinas were examined using confocal laser scanning ophthalmoscopy, fundus autofluorescence, and fluorescein angiography (Heidelberg Spectralis HRA 2; Heidelberg Engineering GmbH, Heidelberg, Germany). Groups of mice were euthanized with carbon dioxide inhalation at days 3 and 7 after laser treatment, and their retinas and choroid-RPE complexes were prepared for fluorescence-based flow cytometry or retina and choroid-RPE whole mounts and histology. All experiments were repeated at least once.

\section{Laser-Induced Choroidal Neovascularization}

Mice were anesthetized, and laser coagulation was performed using a 532-nm argon laser (Visulas 532s; Carl Zeiss Meditec AG, Oberkochen, Germany) with a slit-lamp adapter (Iridex Corp., Mountain View, CA) mounted on a slit lamp (BM900; Haag-Streit AG, Koeniz, Switzerland). Pupil dilation was achieved with tropicamide $0.5 \%$ and phenylephrine $2.5 \%$ eyedrops (Hospital Pharmacy, Inselspital, Bern, Switzerland). Hydroxypropyl methylcellulose, $20 \mathrm{mg} / \mathrm{mL}$ (Methocel 2\%; OmniVision AG, Neuhausen, Switzerland), was applied on the eyes to keep them hydrated. A 2-mm fundus lens (Ocular Instruments, Inc., Bellevue, WA) was used for fundus visualization during the laser application. Three spots per eye were applied around the optic nerve, avoiding the large vessels (50- $\mu \mathrm{m}$ size, 300-mW intensity, 100-millisecond duration), and both eyes were lasered per mouse. Rupture of Bruch membrane was indicated by bubble formation directly after laser application. Lesions with obvious hemorrhage were excluded from analysis. Bridging between laser spots was avoided by positioning the laser sites with sufficient distance.

\section{Fundus Autofluorescence Imaging}

Mice were anesthetized, and their pupils were dilated as described above. To avoid drying of the cornea with 
resulting impairment of image quality, hydroxypropyl methylcellulose, $20 \mathrm{mg} / \mathrm{mL}$, was applied on each eye. Retinal images were acquired using an ultrawide field 102degree lens (Heidelberg Engineering $\mathrm{GmbH}$ ), as described previously. ${ }^{35}$ In MacGreen mice, green fluorescent protein (GFP)-positive cells (microglia/macrophages) could be visualized as hyperfluorescent spots in the autofluorescence images.

\section{Fluorescein Angiography}

After induction of anesthesia and pupil dilation (see above), $50 \mu \mathrm{L}$ of $0.01 \%$ fluorescein [Faure; Novartis, Basel, Switzerland; in $1 \times$ phosphate buffered saline (PBS)] was administered subcutaneously; and images were acquired using the HRA system angiography (Heidelberg Spectralis HRA 2) with a noncontact ultrawide field 102degree lens (Heidelberg Engineering $\mathrm{GmbH}$ ). Images were taken during the first 90 seconds. CNV area was marked and measured using the caliper function in the Heidelberg Eye Explorer version 1.9.17.0 by two blinded assessors (D.K. and P.S.) (Heidelberg Engineering GmbH).

\section{Immunohistochemistry Studies}

For immunohistochemical studies, mouse eyes were isolated for preparation of retinal and choroid-RPE whole mounts. Eyes were fixed in 4\% paraformaldehyde solution $(\mathrm{pH}$ 7.4) for 10 minutes, the anterior segments were removed (cornea and lens), and the posterior segment was incubated for another 50 minutes in paraformaldehyde solution. Retinas were mechanically detached from the choroid-RPE complex, and both tissues were extensively washed in $1 \times$ PBS and $0.5 \%$ Triton X-100 (SigmaAldrich, St. Louis, MO) and processed according to Ebneter et al. ${ }^{36}$ Isolectin GS-IB4 from Griffonia simplicifolia (Alexa Fluor 647 conjugate; 1:100; Thermo Fisher Scientific, Waltham, MA), a rabbit polyclonal antibody against ionized calcium-binding adapter molecule 1 (Iba-1; 1:500; Wako Pure Chemical Industries Ltd., Osaka, Japan), and a chicken polyclonal antibody against GFP (1:300; Abcam, Cambridge, UK) were used for labeling of blood vessels and microglia/macrophages. The secondary antibody goat anti-rabbit IgG H + L (Alexa Fluor 594 conjugate; 1:200; Thermo Fisher Scientific) was used for the visualization of Iba-1 staining, and goat polyclonal antibody to chicken IgY H + L (FICH; 1:200; Abcam) was used for visualization of GFP staining.

Another group of mice was euthanized at days 3 or 7 after CNV induction, and their eyes were fixed in $4 \%$ paraformaldehyde solution ( $\mathrm{pH} 7.4)$ overnight at $4^{\circ} \mathrm{C}$. Eyes were routinely embedded in paraffin, and paraffin sections $(5 \mu \mathrm{m}$ thick) were cut running through the optic nerve head. The slides were deparaffinized and blocked with $10 \%$ normal goat serum for 30 minutes before incubation with a rabbit polyclonal antibody against Iba-1 (see above) overnight at $4^{\circ} \mathrm{C}$. The slides were washed in $1 \times$ PBS and incubated with a secondary biotinylated goat anti-rabbit IgG antibody (1:250; Vector Laboratories, Burlingame, CA), for 30 minutes in room temperature, followed by three washes with $1 \times$ PBS and incubation with a horseradish peroxidase-streptavidin conjugate (1:1000; Vector Laboratories) for 60 minutes at room temperature. The signal was visualized using the NOVA red substrate kit (Vector Laboratories), according to manufacturer's instructions.

\section{Microscopy}

For retinal or choroid-RPE whole mounts, microscopy was performed on equipment provided by the Microscopy Imaging Center, University of Bern (Bern, Switzerland). Retinal and choroid-RPE flat mounts were examined using an inverted Zeiss LSM 710 fluorescence confocal microscope (Carl Zeiss Meditec AG, Jena, Germany). Z-stacks of 100 to $110 \mu \mathrm{m}$ with $5-\mu \mathrm{m}$ intervals were obtained. Eye sections were examined under a fluorescence Nikon Eclipse 80i microscope (Nikon, Tokyo, Japan). CorelDraw X6 (Corel Corp., Ottawa, ON, Canada) was used for figure preparation.

\section{Flow Cytometry}

Retinas and choroid-RPE complexes from MacGreen mice were used for flow cytometry analysis at days 3 and 7 after the laser application. The eyes were collected in PBS ( $\mathrm{pH} 7.4)$, the anterior segment was removed, the retina was mechanically detached from the choroid-RPE complex, and both tissues were used for flow cytometry. Retinas or choroid-RPE of each individual mouse were analyzed as one sample. Tissues were processed according to Ebneter et al. ${ }^{36}$ Retinas were stained with fluorescent-labeled antibodies against CD45-allophycocyanin/ Cy7 (30-F11; 1:400), CD11b-allophycocyanin (M1/70; 1:200), and major histocompatibility complex class-II-Pacific blue (AF6-120.1; 1:200). Choroid-RPE samples were stained with fluorescent-labeled antibodies against CD11b-allophycocyanin (M1/70; 1:200), CD11c-allophycocyanin/Cy7 (N418; 1:200), Ly6G-PerCP/Cy5.5 (1A8; 1:200), Ly6C-Brilliant Violet 405 (HK1.4; 1:100), NK-1.1-phycoerythrin/Dazzle 594 (PK146; 1:200), CD3-phycoerythrin/Dazzle 594 (17A2; 1:200), and CD19-phycoerythrin/Dazzle 594 (6D5; 1:200). Zombie Red Fixable Viability Kit (1:800; Biolegend, San Diego, CA) staining was used for detection of dead cells, according to manufacturer's instructions. Samples were incubated for 20 minutes with an Fc blocker (1:200; Biolegend), followed by incubation with the fluorescent-labeled antibodies for 20 more minutes at $4^{\circ} \mathrm{C}$ in the dark. Each experiment was repeated at least once.

An LSR II Cytometer System with the BD FACSDiva software version 4.1 (BD Biosciences, Allschwil, Switzerland) was used for data acquisition. The flow cytometry data were analyzed with the Flowjo Single Cell 
Analysis Software version 10 (TreeStar, Ashland, OR). All antibodies were purchased from Biolegend.

\section{Protein Extraction}

In total, $34 \mathrm{C} 57 \mathrm{BL} / 6 \mathrm{~J}$ mice were used for protein extraction and analysis of cytokine and chemokine levels. Control or PLX5622-fed mice were lasered, as mentioned above, 1 week after the initiation of the PLX5622 diet; and proteins were extracted from the posterior part of the eyes at days 3 and 7 after CNV. Ten naïve mice were used as naive controls, and four eyecups were pooled as one sample. Briefly, the eyecups were homogenized in $200 \mu \mathrm{L}$ of lysis buffer $\left[1 \times\right.$ lysis buffer provided with the kit, $1 \mathrm{mmol} / \mathrm{L} \mathrm{Na}_{3} \mathrm{VO}_{4}$, protease inhibitor cocktail (cOmplete ULTRA Tablets, EDTA-free; Roche, Basel, Switzerland)] and homogenized using a Precellys 24 tissue homogenizer (Bertin Instruments, Montigny-le-Bretonneux, France). After centrifugation for 10 minutes at $15,870 \times g$ at $4^{\circ} \mathrm{C}$, the supernatant was collected and Bradford assay was used for the determination of total protein content.

\section{Mouse Inflammation Antibody Array Membranes}

Mouse inflammation antibody array membranes (ab193660; Abcam) were processed according to manufacturer's instructions. Briefly, the membranes were incubated for 2 hours in blocking buffer (provided with the kit) and incubated with $500 \mu \mathrm{g}$ of total protein, overnight at $4^{\circ} \mathrm{C}$. Membranes were washed (wash buffer provided with the kit) and incubated with biotin-conjugated anti-cytokines/ chemokines (provided with the kit) in blocking buffer, overnight at $4{ }^{\circ} \mathrm{C}$, and incubated with $1 \times$ horseradish peroxidase-conjugated streptavidin (provided with the kit), for 2 hours at room temperature. Chemiluminescence was detected using detection buffers (provided with the kit) and a Fusion Pulse Imaging System (Witec AG, Luzern, Switzerland). Densitometry analysis was performed using the Protein Array Analyzer function of the ImageJ version 1.52h (NIH, Bethesda, MD; https://imagej.net/imagej). ${ }^{37}$ The signal was normalized between different membranes using the positive control spots. Spots with abnormally high background were excluded from the analysis. The experiment was repeated once.

\section{Statistical Analysis}

The sample size was estimated in the GPower 3.1 software $^{38}$ on the basis of a power of $0.8(80 \%)$ and a significance level of $0.05(5 \%)$. The standardized difference of each experimental group was estimated on the basis of previous studies and pilot experiments. ${ }^{25,26}$ D'AgostinoPearson omnibus test or Kolmogorov-Smirnov test was used to test the normal distribution of different data sets. Repeated-measures one-way analysis of variance was used for the analysis of the CNV course with or without
PLX5622 treatment. To compare the CNV area between PLX5622-treated and nontreated mice, ordinary one-way analysis of variance was used, followed by Tukey post hoc analysis. Statistically significant differences of the flow cytometry data were determined using one-way analysis of variance, followed by Tukey post hoc analysis for normally distributed data and Kruskal-Wallis test, followed by Dunn multiple comparison test for the data that did not follow normal distribution. Kruskal-Wallis test, followed by Dunn multiple comparison test, was used for the comparison of the array membrane data. All data are expressed as means $\pm \mathrm{SD}$.

$P<0.05$ was considered statistically significant. GraphPad Prism 5.0 software (GraphPad Software, Inc., San Diego, CA) was used for the statistical analysis.

\section{Results}

\section{Effect of CSF-1R Inhibition in the Time Course of Laser- Induced CNV}

Inhibition of the CSF-1R with PLX5622 for 7 days before $\mathrm{CNV}$ induction (Figure 1A) led to a striking reduction of GFP-positive cells in the retinas of MacGreen mice (Figure 1B). Laser application resulted in comparable CNV areas between PLX5622-treated and untreated mice 3 days after the CNV induction (Figure 1C). However, the area of $\mathrm{CNV}$ was decreased at later time points in the CNV group (Figure 1C), whereas the presence of PLX5622 resulted in an accelerated involution of $\mathrm{CNV}$ area over time (Figure 1C). The leakage area of CNVs on the fluorescein angiographs substantiated this finding $(P<0.001$, repeatedmeasures one-way analysis of variance with Tukey post hoc analysis) (Figure 1D). Moreover, at day 14, there was a statistically significant decrease in CNV size of mice fed with PLX5622 compared with control-fed mice $(P<0.001$, ordinary one-way analysis of variance with Tukey post hoc analysis).

In the choroid-RPE complex, $\mathrm{CNV}$ areas were identified using isolectin GS-IB4 staining (Figure 2A). Iba-1-positive cells representing microglia/macrophages accumulated around the lesion sites in the choroid-RPE and retinal whole mounts of control mice (Figure 2A). In the PLX5622 group, Iba-1-positive cells, most probably representing macrophages, were present in CNV areas of the choroid-RPE but were absent from the neurosensory retina (Figure 2A). In the choroid-RPE as well as in the outer retina, Iba-1-positive cells' morphology suggested a reactive phenotype, whereas in the inner retina, most of the Iba-1-positive cells had a ramified morphology (Figure 2B). Iba-1-positive cells were also detected in eye sections around the lasered area of CNV-subjected mice, and their numbers were greatly reduced in the presence of PLX5622 (Figure 2C). In the choroid-RPE complex of MacGreen CNV-subjected mice, most CSF-1R-GFP-positive cells were colocalized with Iba-1, whereas a few cells were Iba-1 negative (Figure 2D). 
A

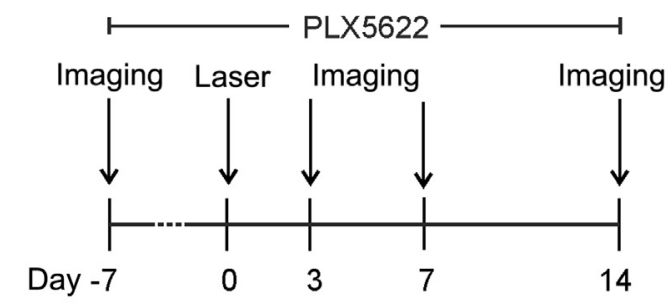

B

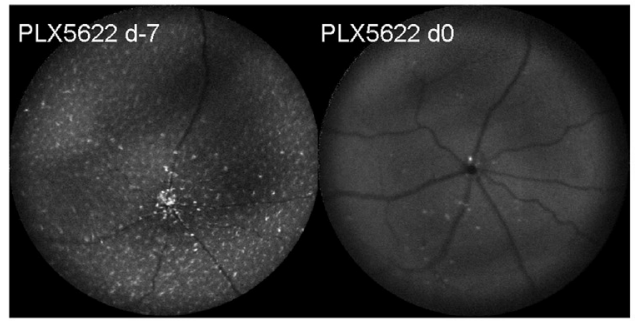

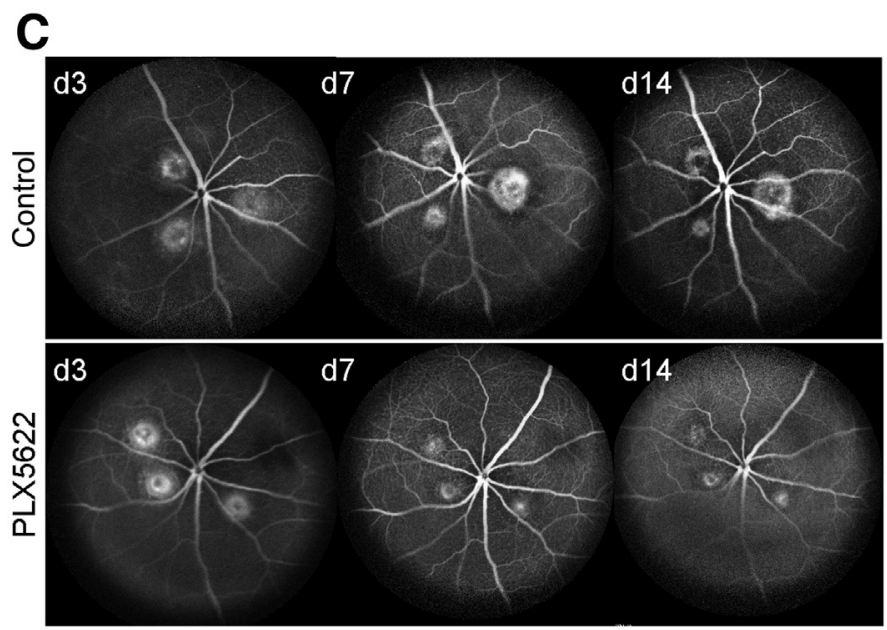

D

\section{- CNV \\ PLX5622+CNV}

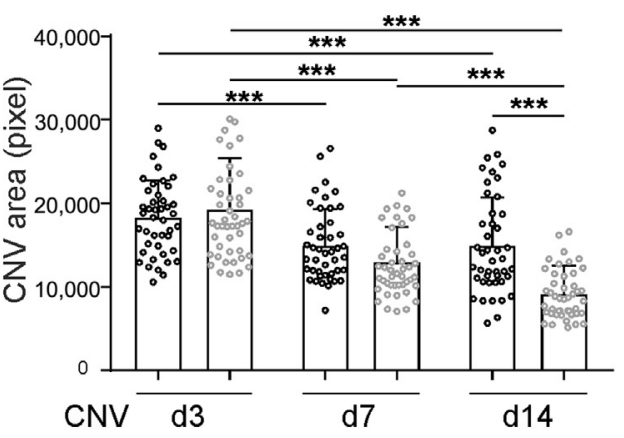

Figure 1 Effect of colony-stimulating factor-1 receptor inhibition on choroidal neovascularization (CNV). A: Experimental setup. B: Representative autofluorescence images of a MacGreen mouse retina before (PLX5622 day-7) and 7 days after the start of PLX5622 diet (PLX5622 day 0). Green fluorescent protein-positive microglia cells are drastically diminished in the retina after 7 days of PLX5622 diet. C: Representative fluorescein angiographs of CNVsubjected eyes at different time points in control or PLX5622-fed mice. D: CNV area measurements in fluorescein angiographs of control or PLX5622-fed mice. CNV area was gradually decreased in control (CNV) and PLX5622-fed mice. Repeated-measures one-way analysis of variance, followed by Tukey post hoc analysis, was used. Statistically significant reduction of the lesion size was observed in the presence of PLX5622 at day 14 compared with the control. Ordinary one-way analysis of variance, followed by Tukey post hoc analysis, was used. Individual CNV lesions are plotted in the graph. $n=3$ (B); $n \geq 14$ eyes per group (D). ${ }^{* * * P}<0.001$.

\section{Quantification of Retinal Microglia and Macrophage Populations with Flow Cytometry}

Flow cytometry was performed at days 3 and 7 after $\mathrm{CNV}$ in the retina of control and PLX5622-treated CNV-subjected mice (Figure 3A). The cells were gated as shown in Supplemental Figure S1A. CNV induced accumulation of $\mathrm{CD} 45^{\text {low }} \mathrm{CD} 11 \mathrm{~b}^{+}$microglia and $\mathrm{CD} 45^{\text {hi }} \mathrm{CD} 11 \mathrm{~b}^{+}$macrophages $^{39}$ in the retina, whereas PLX5622 reduced their numbers (Figure 3A). Quantification of different cell populations revealed that the number of microglia and macrophages was elevated 3 and 7 days after $\mathrm{CNV}(P<0.001$, ordinary one-way analysis of variance with Tukey post hoc analysis) (Figure 3B). In mice fed with PLX5622, microglia cells were diminished by approximately $98.5 \%$ compared with control $\mathrm{CNV}$ mice at day 3 and day 7 after $\mathrm{CNV}$ $(P<0.001$, ordinary one-way analysis of variance with Tukey post hoc analysis) (Figure 3B). Similarly, PLX5622 led to a reduction of macrophages by $47.7 \%$ and $76.3 \%$ compared with control at days 3 and 7 , respectively, after CNV induction $(P<0.001$, ordinary one-way analysis of variance with Tukey post hoc analysis) (Figure 3B). No statistically significant difference was observed in CSF-1R expression in different cell types for different treatments and time points (Figure 3C). Increased major histocompatibility complex class-II expression in both microglia and macrophages was observed at day 3 after $\mathrm{CNV}(P<0.001$, Kruskal-Wallis test, followed by Dunn multiple comparison test) (Figure 3C). In mice fed with PLX5622, major histocompatibility complex class-II expression in microglia and macrophages was virtually absent (Figure 3C).

Quantification of Immune Cell Population in the Choroid-RPE with Flow Cytometry

Flow cytometry was performed at days 3 and 7 after $\mathrm{CNV}$ in the choroid-RPE of control and PLX5622-treated mice. The cells were gated as shown in Supplemental Figure S1B. The numbers of $\mathrm{CD} 11 \mathrm{c}^{+}$cells, most of which most probably represents dendritic cells ${ }^{40}$ leukocytes $\left(\mathrm{CD} 11 \mathrm{~b}^{+} \mathrm{CD} 11 \mathrm{c}^{\text {neg }}\right),{ }^{41}$ and neutrophils $\left(\mathrm{CD} 11 \mathrm{~b}^{+} \mathrm{Ly}_{6 \mathrm{G}}{ }^{+}\right)^{40}$ were elevated in the choroid-RPE during the acute phase of $\mathrm{CNV}(P<0.05$, $P<0.01$, and $P<0.001$, respectively; ordinary one-way 


\section{A}
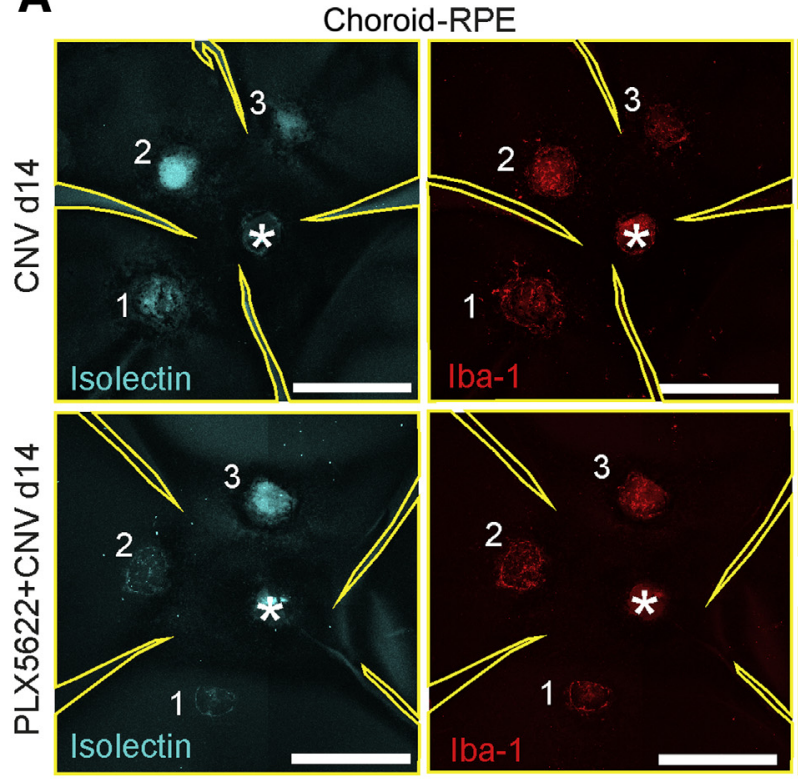

C
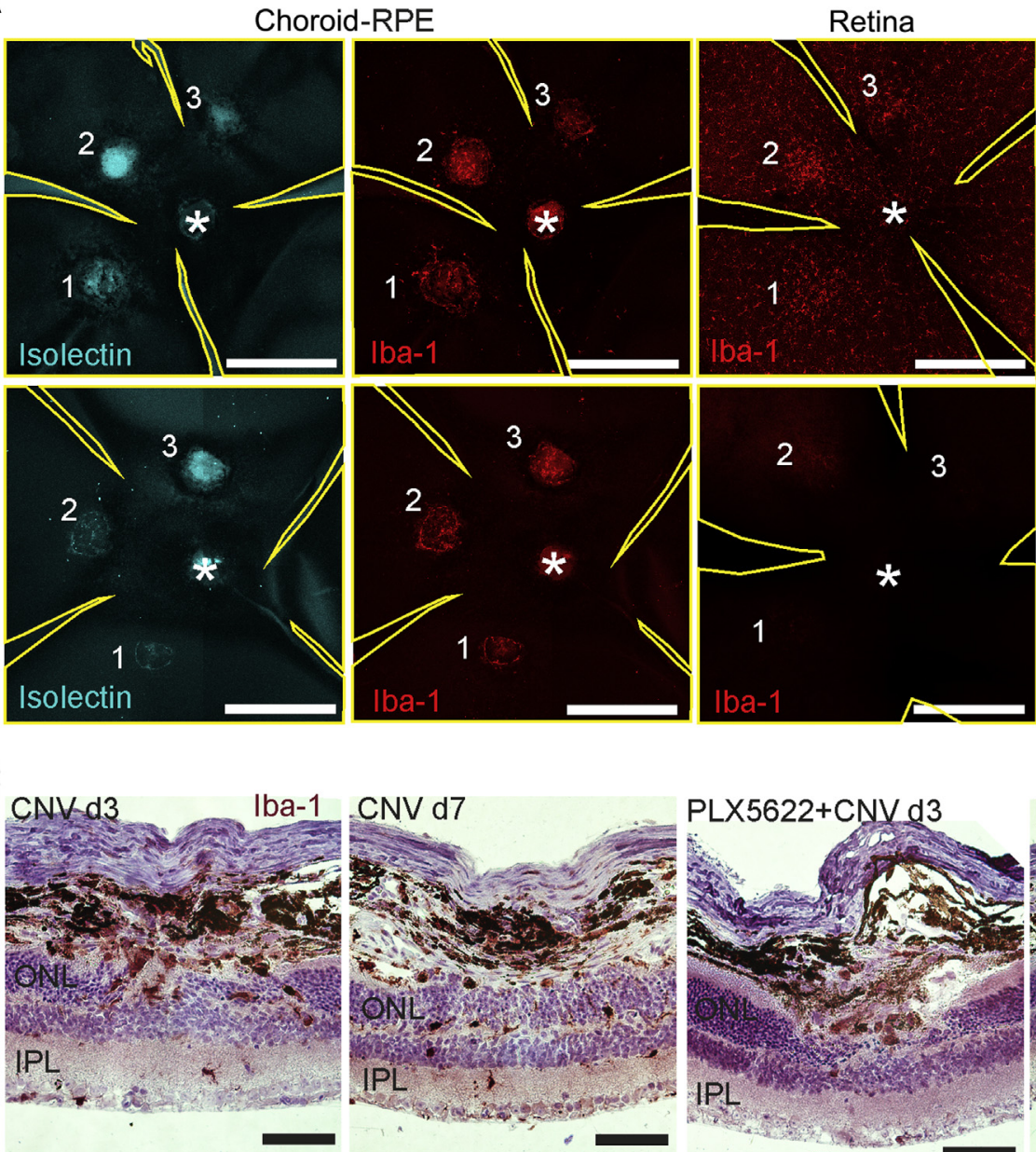

B
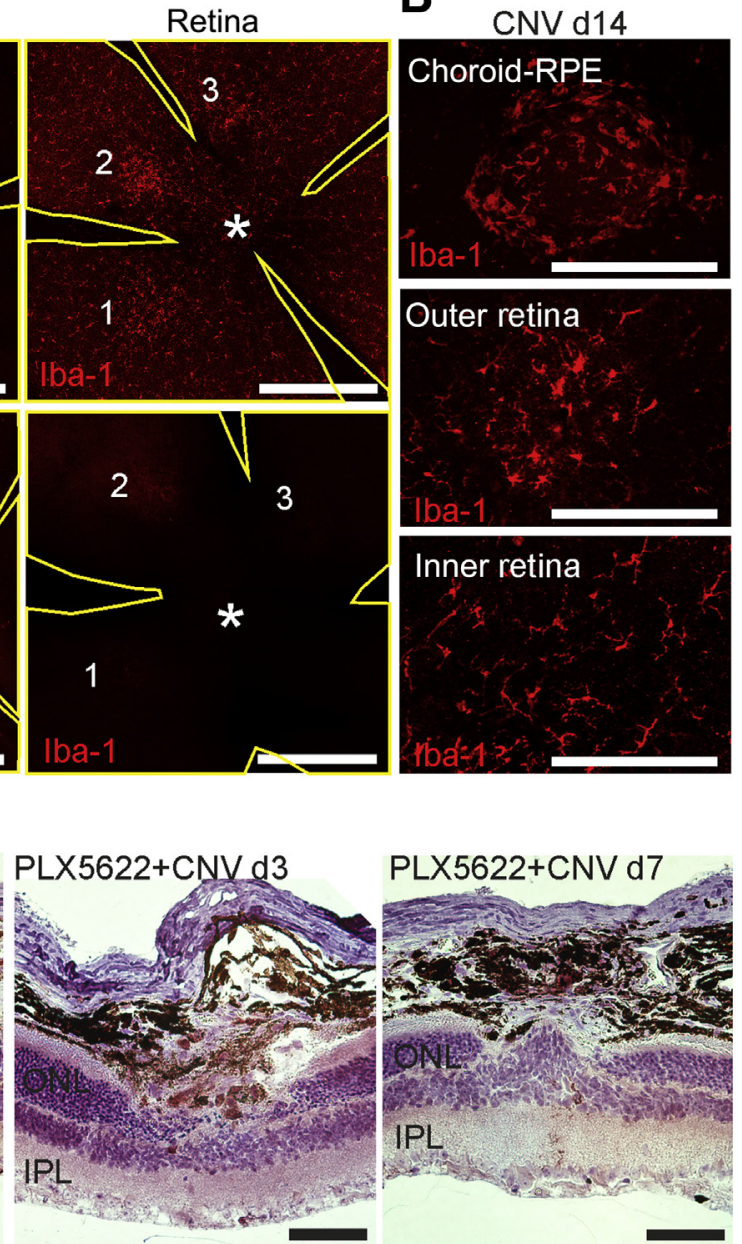

D
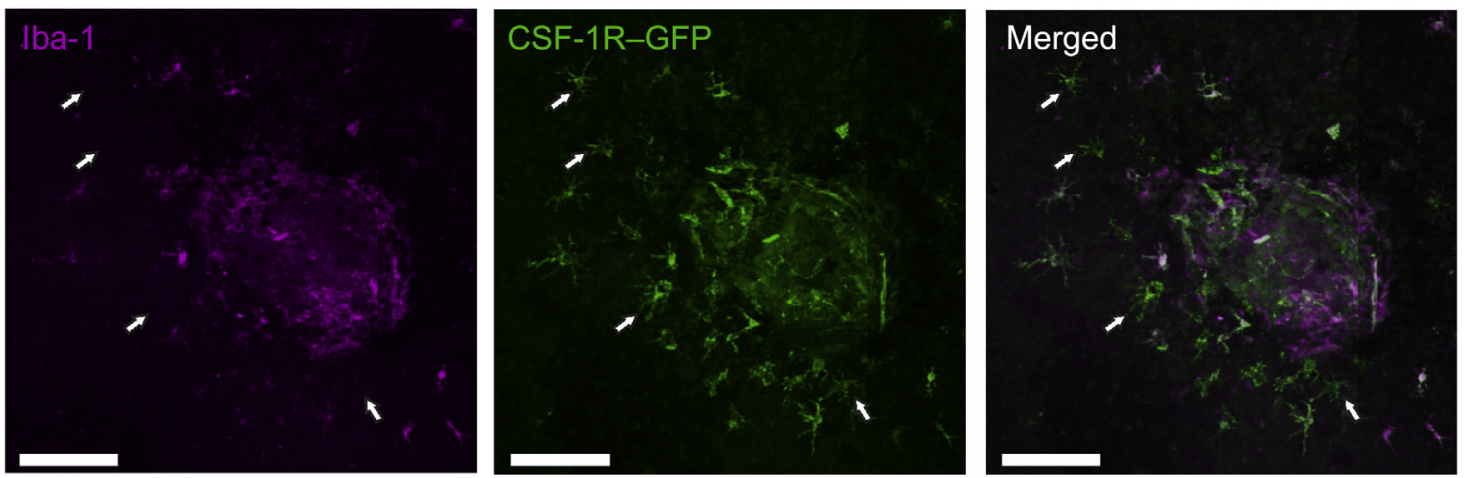

Figure 2 Ex vivo evaluation of microglia and accumulation of monocyte-derived macrophages in the laser site. A: Isolectin and ionized calcium-binding adapter molecule 1 (Iba-1) staining in the choroid-retinal pigment epithelium (RPE) whole mounts and Iba-1 staining in retinal whole mounts 14 days after choroidal neovascularization (CNV) in control and PLX5622-fed mice. Iba-1-positive cells accumulate at the laser site in the choroid-RPE and in the retina of control CNV-subjected mice. In PLX5622-fed mice, Iba-1-positive cells are detected in the choroid-RPE but not in the retinal whole mounts. Numbers indicate the three different laser spots; asterisks, the optic nerve head; yellow lines, the area of the whole mounts. B: Higher magnification of Iba-1 staining in control-fed mice subjected to CNV, 14 days after the laser application. In the choroid-RPE and the outer retina, Iba-1-positive cells accumulated around the laser site and their morphology is characterized by increased soma size and retracted processes. In the inner retina, a ramified morphology is observed. C: Representative photomicrographs of Iba-1-positive cells in retinal sections of control or PLX5622-fed CNV-subjected mice. Iba-1-positive cells accumulated in the outer retina and the choroid-RPE in the CNV eyes (first and second panels). In mice fed with PLX5622, Iba-1-positive cells also accumulated in the outer retina and choroid-RPE; however, they were fewer in number and were almost absent 7 days after CNV (third and fourth panels). D: Representative photomicrographs of Iba-1- and colony-stimulating factor-1 receptor-green fluorescent protein (CSF-1R-GFP)-positive cells in retinal sections of control or PLX5622-fed mice 14 days after CNV. Most of the CSF-1R-GFP-positive cells are colocalized with Iba-1, whereas a few of them are Iba-1 negative (arrows). $n \geq 6$ mice per group (A); $n \geq 3$ mice per time point (C and D). Scale bars: $500 \mu \mathrm{m}(\mathbf{A}) ; 200 \mu \mathrm{m}$ (B and C); $100 \mu \mathrm{m}$ (D). Original magnification: $\times 10$ (A); $\times 40$ $(B$ and $\mathbf{D}) ; \times 20($ C). IPL, inner plexiform layer; 0 NL, outer nuclear layer. 
A

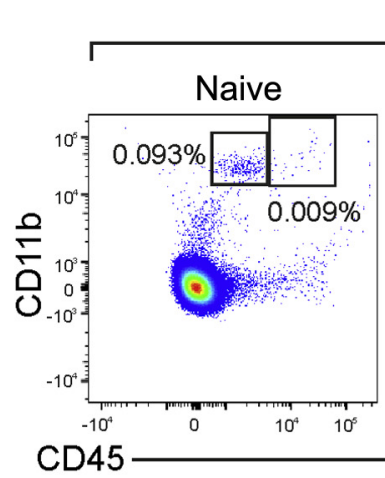

Standard rodent diet

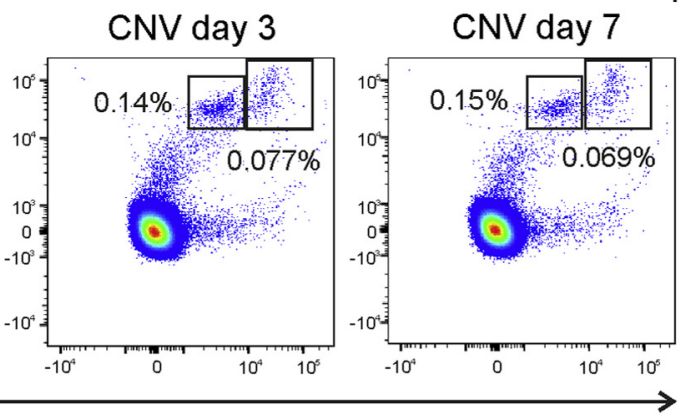

PLX5622 diet

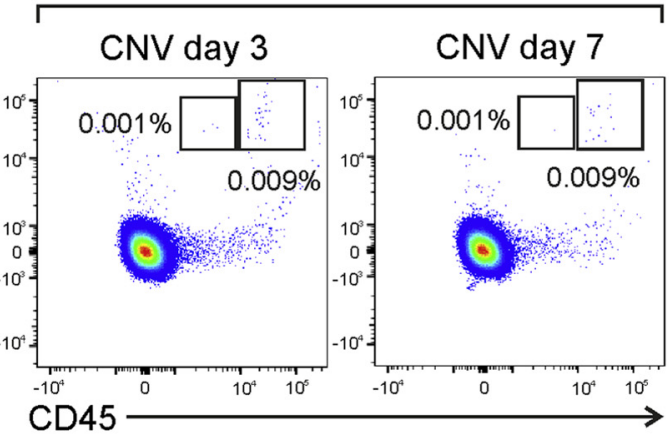

B
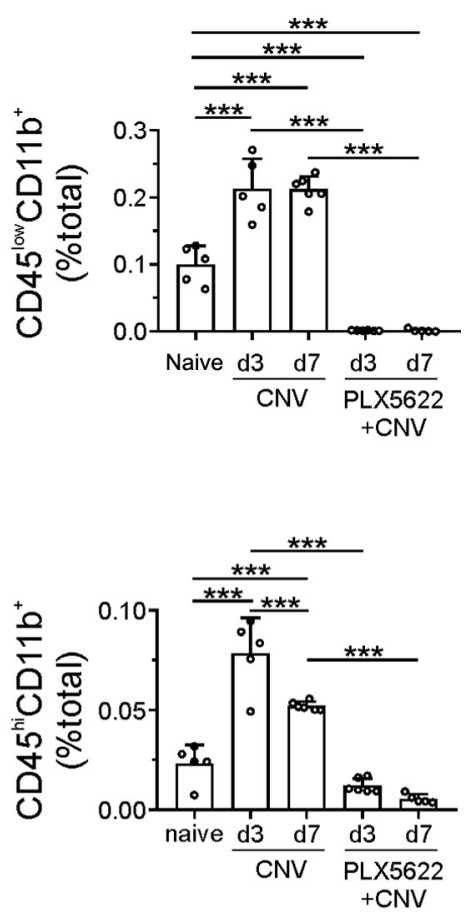

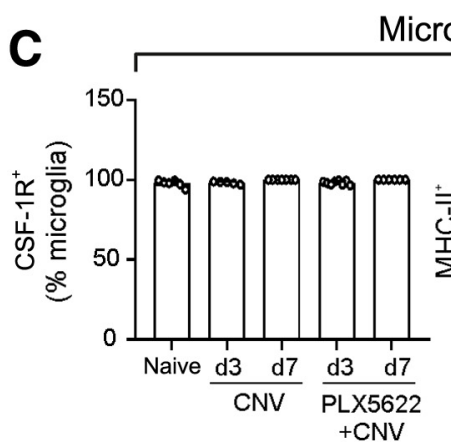

Microglia
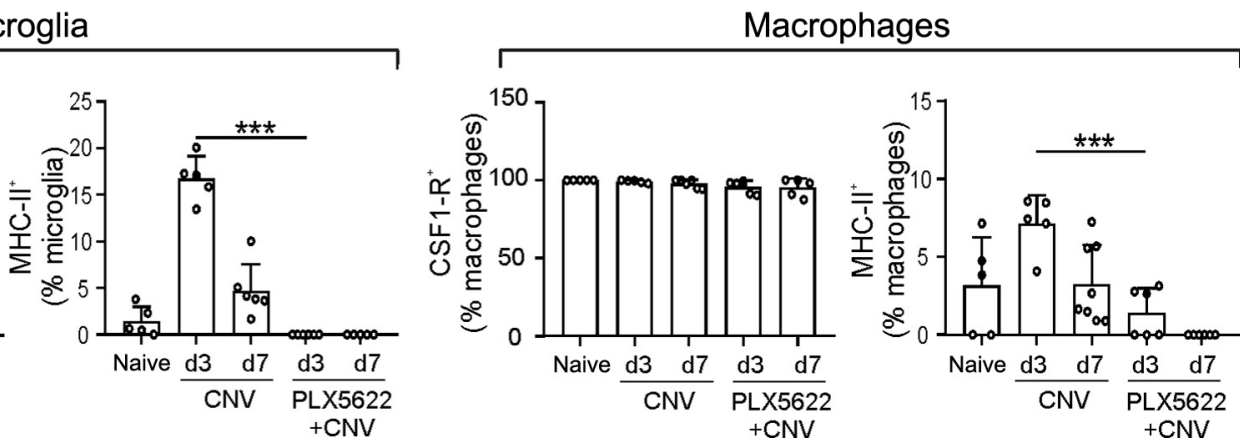

Figure 3 Flow cytometry analysis of microglia/macrophage population in the retina of choroidal neovascularization (CNV)-subjected mice. A: Representative flow cytometry plots at different time points after CNV in control and PLX5622-fed animals. Microglia were identified as CD45 ${ }^{\text {low }}$ CD11 ${ }^{+}$and macrophages as $\mathrm{CD} 45^{\text {hi }} \mathrm{CD}_{11} \mathrm{~b}^{+}$. B: Quantification of microglia (CD45 ${ }^{\text {low }} \mathrm{CD} 11 \mathrm{~b}^{+}$; top panel) and macrophages (CD $45^{\text {hi }} \mathrm{CD} 11 \mathrm{~b}^{+}$; bottom panel) in the retina, 3 and 7 days after CNV, in the presence or absence of PLX5622. Elevated number of microglia and macrophages is observed 3 and 7 days after CNV. PLX5622 reduces the number of microglia and macrophages in the retina. C: Quantification of colony-stimulating factor-1 receptor-positive (CSF-1 $\mathrm{R}^{+}$) or major

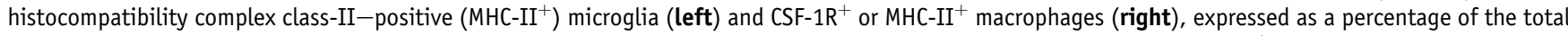
number of microglia or macrophages, respectively. No statistically significant difference was observed in the number of CSF- $1 \mathrm{R}^{+}$microglia and macrophages in the presence or absence of PLX5622. MHC-II ${ }^{+}$microglia and macrophages were detected in the retina at the early course of CNV (day 3), yet this increase was not statistically significant compared with the naive tissue. PLX5622 reduces the expression of MHC-II by these cells. One-way analysis of variance, followed by Tukey post hoc analysis, or Kruskal-Wallis test, followed by Dunn multiple comparison test, was used. $n \geq 5$ mice per group (B and $\mathbf{C})$. ${ }^{* * *} P<0.001$.

analysis of variance with Tukey post hoc analysis for CD11 ${ }^{+}$cells and leukocytes and Kruskal-Wallis test, followed by Dunn multiple comparison test, for neutrophils) (Figure 4A), whereas PLX5622 led to a reduction of CD11 $\mathrm{c}^{+}$ cells and leukocyte numbers below control (naive) levels (Figure 4A). Interestingly, although there was no difference between the naïve and the $\mathrm{CNV}$-subjected tissues in the total number of $\mathrm{Ly}_{6 \mathrm{G}^{\text {neg }}} \mathrm{Ly} 6 \mathrm{C}^{\text {low/neg }}$ side scatter $(\mathrm{SSC}-\mathrm{H})^{\text {low }}$ cells, representing nonclassic patrolling monocytes/macrophages, ${ }^{42}$ the presence of PLX5622 led to a reduction of these cell numbers below control (naive) levels $(P<0.001$, ordinary one-way analysis of variance with Tukey post hoc analysis) (Figure 4B). Classic inflammatory monocytes/macrophages $\left(\mathrm{Ly} 6 \mathrm{G}^{\mathrm{neg}} \mathrm{Ly} 6 \mathrm{C}^{\mathrm{hi}}\right),{ }^{42}$ on the other hand, were increased at day 3 after $\mathrm{CNV}$; and this was prevented by PLX5622 $(P<0.001$, ordinary one-way analysis of variance with Tukey post hoc analysis) (Figure 4B). The expression of CSF-1R by patrolling and inflammatory monocytes, 
A $\quad$ CD11 $c^{+}$cells

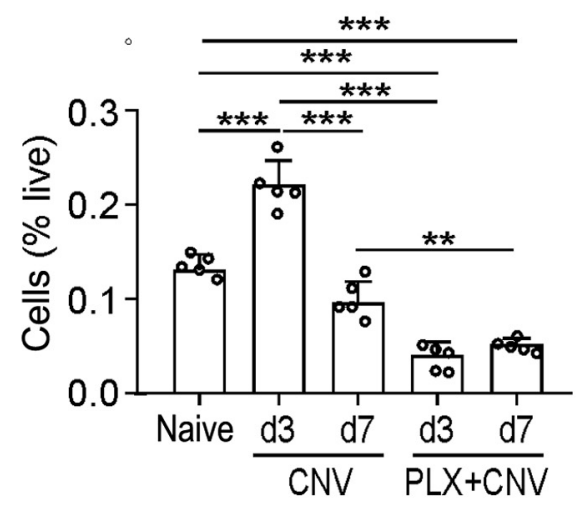

B

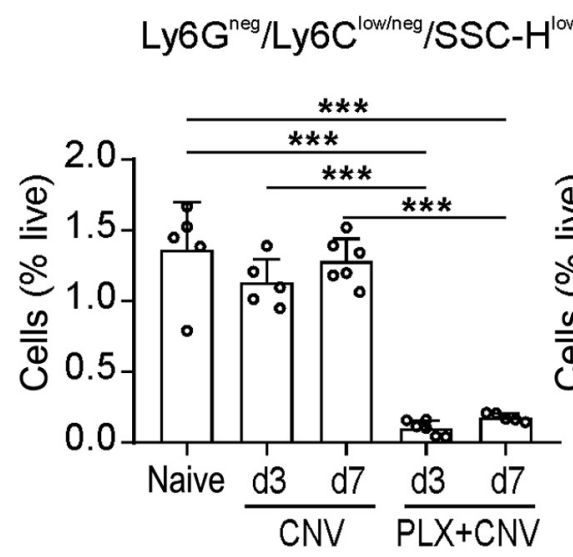

C

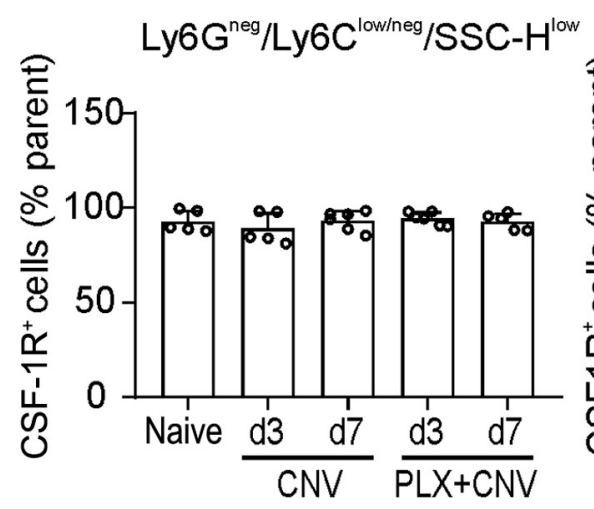

Leukocytes

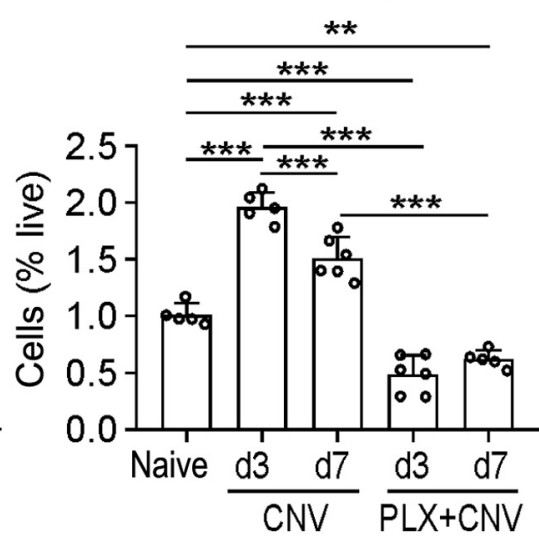

$\operatorname{Ly}^{\text {Geg }} /$ Ly6C $^{\text {hi }}$
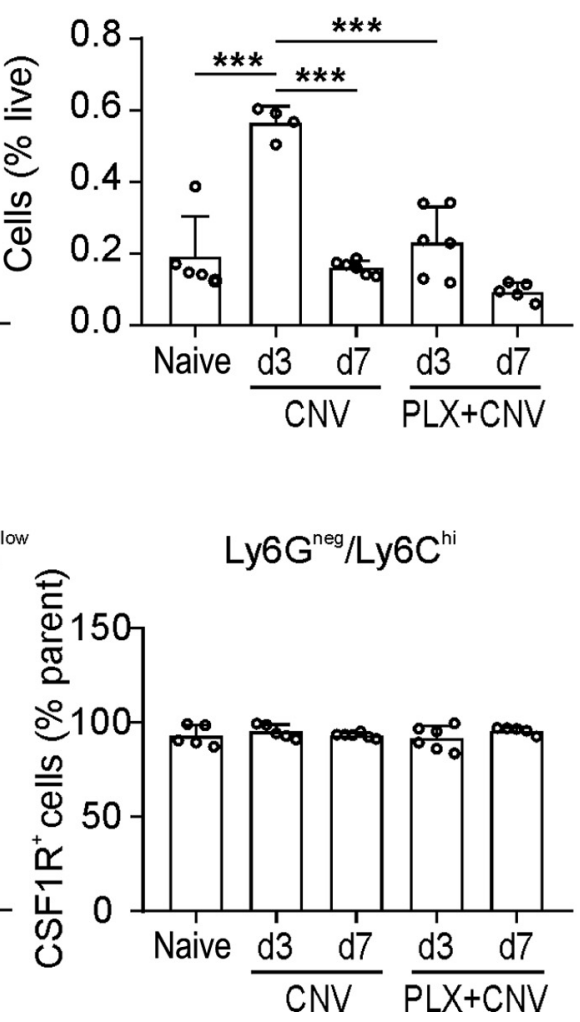

Neutrophils

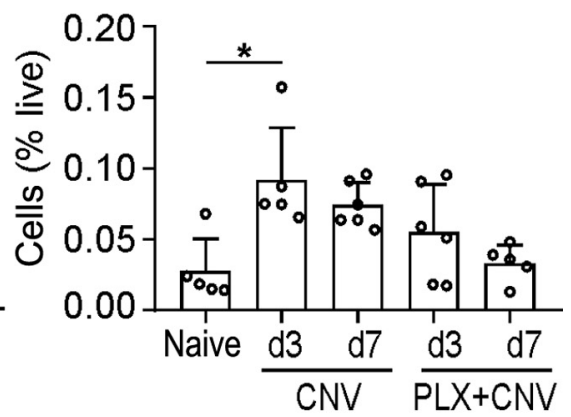

Figure 4 Quantification of immune cell population in the choroid-retinal pigment epithelium (RPE) using flow cytometry analysis. A: The numbers of $\mathrm{CD} 11 \mathrm{c}^{+}$cells (left) in the choroid-RPE are elevated 3 days after choroidal neovascularization (CNV) and return to control levels at day 7 after CNV. PLX5622 (PLX) reduces CD11c $^{+}$cell numbers below control levels. Leukocyte numbers (middle) peak at day 3 after $\mathrm{CNV}$, and their numbers are reduced in the presence of PLX5622. A slight increase in neutrophil numbers is detected 3 days after CNV (right). B: Leukocytes were further gated on the basis of the expression of Ly6G and Ly6C. Ly6G ${ }^{\text {neg }}$ Ly6C ${ }^{\text {low/neg }}$ side scatter (SSC)- $H^{\text {low }}$ cells are reduced in the presence of PLX5622, whereas no differences are observed between the naïve and CNV-subjected tissues (left). On the other hand, Ly $6 \mathrm{G}^{\text {neg }} \mathrm{Ly} 6 \mathrm{C}^{\text {hi }}$ inflammatory monocytes/macrophages are increased 3 days after CNV and decreased thereafter (right); and this phenomenon is prevented by PLX5622. C: No difference is observed in the expression of colony-stimulating factor-1 receptor (CSF-1R) by Ly6 $\mathrm{G}^{\text {neg }} \mathrm{Ly}^{\mathrm{C}} \mathrm{C}^{\text {low/neg }} \mathrm{SSC}-\mathrm{H}^{\text {low }}$ (left) or Ly6G $\mathrm{G}^{\text {neg }}$ Ly6 $\mathrm{C}^{\text {hi }}$ monocytes/macrophages (right) between different treatments. Ordinary one-way analysis of variance with Tukey post hoc analysis or Kruskal-Wallis test, followed by Dunn multiple comparison test, was used. $n \geq 5$ for each treatment $(\mathbf{A}-\mathbf{C}) .{ }^{*} P<0.05,{ }^{*} P>0.01$, and $* * * P<0.001$. expressed as a percentage of $\mathrm{Ly} 6 \mathrm{G}^{\text {neg }} \mathrm{Ly} 6 \mathrm{C}^{\text {low/neg }} \mathrm{SSC}-\mathrm{H}^{\text {low }}$ and $\mathrm{Ly}_{6 \mathrm{G}}{ }^{\text {neg }} \mathrm{Ly} 6 \mathrm{C}^{\mathrm{hi}}$ cells, respectively, was not altered between the different groups (Figure 4C).

\section{Cytokine Levels during the Course of CNV}

The protein levels of several inflammatory modulators, such as chemokines [chemokine (C-C motif) ligands 3 and 9], growth factors [insulin-like growth factor-binding protein (IGFBP)-3, IGFBP-5, and granulocyte-macrophage colony-stimulating factor], members of the tumor necrosis factor (TNF) superfamily [CD30 ligand and soluble TNF receptor (TNFR) I], inflammatory cytokines (interferon- $\gamma$, IL-1 $\alpha$, and IL-12 p70), anti-inflammatory cytokines (IL-13), matrix metalloproteinases (MMP-2 and MMP-3), Fc $\gamma$ receptors (Fc- $\gamma$ RIIB), and adhesion molecules [vascular cell adhesion molecule 1 (VCAM-1)], were elevated at the acute phase of the disease (Table 1) 3 days after laser application. During the later phase (day 7), most of the inflammatory modulators returned to control levels, except for an 
Table 1 Effect of Laser-Induced CNV on Cytokine/Chemokine Levels in the C57BL/6J Mouse Eyecups in the Presence or Absence of PLX5622

\begin{tabular}{|c|c|c|c|c|}
\hline \multirow[b]{2}{*}{ Factors } & \multicolumn{2}{|l|}{ Day 3} & \multicolumn{2}{|l|}{ Day 7} \\
\hline & CNV & $\begin{array}{l}\text { CNV + } \\
\text { PLX5622 }\end{array}$ & CNV & $\begin{array}{l}\text { CNV + } \\
\text { PLX5622 }\end{array}$ \\
\hline CCL3 & $1.60^{*}$ & 1.11 & $0.85^{\ddagger \ddagger}$ & 0.55 \\
\hline CCL9 & $1.58 * * *$ & $2.36 * * * \dagger \dagger \dagger$ & 1.26 & $2.62 * * * t \dagger \dagger$ \\
\hline CX3CL1 & 1.34 & $4.59 * * *$ & 1.39 & $3.75^{* * *}$ \\
\hline CXCL16 & 1.29 & $2.38 * * * \dagger \dagger \dagger$ & 1.11 & $2.45^{* * * \dagger \dagger \dagger}$ \\
\hline \multicolumn{5}{|c|}{ Growth factors } \\
\hline bFGF & 1.67 & $2.06^{*}$ & $2.12^{* * *}$ & $3.00 * * * \dagger$ \\
\hline IGFBP-3 & $1.33^{* *}$ & $1.83^{* * * \dagger \dagger \dagger}$ & 1.08 & $1.70 * * *+\dagger \dagger$ \\
\hline IGFBP-5 & $1.45^{*}$ & $2.41 * * * \dagger \dagger \dagger$ & 1.12 & $1.92 * * * \dagger \dagger \dagger$ \\
\hline CD30 & 1.21 & $2.03 * * \dagger$ & 1.09 & 1.54 \\
\hline CD30L & $1.43^{*}$ & 1.40 & 1.09 & 0.92 \\
\hline Fas ligand & 0.79 & $1.75^{\dagger \dagger}$ & 0.85 & 0.93 \\
\hline sTNFRI & $1.53^{*}$ & $2.58^{* * * \dagger \dagger \dagger}$ & $0.86^{\ddagger \ddagger}$ & $2.35^{* * * \dagger \dagger \dagger}$ \\
\hline \multicolumn{5}{|c|}{ Proinflammatory cytokines } \\
\hline IFN- $\gamma$ & $1.70^{*}$ & $0.54^{\dagger \dagger \dagger}$ & $1.14^{\ddagger}$ & $0.46^{\dagger}$ \\
\hline $\mathrm{IL}-1 \alpha$ & $1.34^{*}$ & $2.31 * * * \dagger \dagger \dagger$ & 1.12 & $1.60 * * * \dagger \dagger+\dagger \ddagger$ \\
\hline IL-12 p70 & $1.48^{* *}$ & $1.76 * * *$ & $1.09^{\ddagger}$ & $1.50 *$ \\
\hline TCA-3 & 1.20 & $1.86 * * * \dagger \dagger \dagger$ & 0.95 & $1.73 * * * t \dagger \dagger$ \\
\hline TIMP-1 $\alpha$ & 1.23 & $1.59 * *$ & 0.93 & $1.41^{\dagger}$ \\
\hline \multicolumn{5}{|c|}{ Anti-inflammatory cytokines } \\
\hline Fc $\gamma$ RIIB & $2.19 * *$ & $0.43^{\dagger \dagger}$ & 1.45 & 0.89 \\
\hline \multicolumn{5}{|c|}{ Adhesion molecules } \\
\hline VCAM-1 & $1.54^{* *}$ & $2.84^{* * * \dagger \dagger \dagger}$ & $1.57^{* * *}$ & $3.47 * * * t \dagger \dagger$ \\
\hline
\end{tabular}

Semiquantitative analysis of inflammatory mediators' protein levels in the retina-choroid-retinal pigment epithelium complex, 3 and 7 days after CNV, in the presence or absence of PLX5622. All data are normalized to naive tissues. Only targets with statistically significant differences are shown in the table. Targets that were examined but did not show statistically significant differences included IL-6, TNF- $\alpha$, vascular endothelial growth factor, monocyte chemoattractant protein 1 (MCP-1), G-CSF, and CCL5, among others.

${ }^{*} P<0.05,{ }^{* *} P<0.01$, and ${ }^{* * *} P<0.001$ versus naïve.

${ }^{\dagger} P<0.05,{ }^{\dagger \dagger} P<0.01$, and ${ }^{\dagger \dagger} P<0.001$ versus CNV.

${ }^{\ddagger} P<0.05,{ }^{\ddagger \ddagger} P<0.01$, and ${ }^{\ddagger \ddagger \ddagger} P<0.001$ versus the same treatment at day 3 .

bFGF, basic fibroblast growth factor; CD30L, CD30 ligand; CCL, chemokine (C-C motif) ligand; CNV, choroidal neovascularization; CX3CL-1, chemokine (C-X3-C motif) ligand 1; GM-CSF, granulocyte-macrophage colony-stimulating factor; IFN- $\gamma$, interferon- $\gamma$; IGFBP, insulin-like growth factor-binding protein; MMP, matrix metalloproteinase; sTNFR, soluble TNF receptor; TCA-3, chemokine (C-C motif) ligand 1 or CCL1; TIMP1, TIMP metallopeptidase inhibitor 1; TNF, tumor necrosis factor; VCAM, vascular cell adhesion molecule.

elevation of the protein levels of basic fibroblast growth factor, granulocyte-macrophage colony-stimulating factor, and VCAM-1. In the presence of PLX5622, protein levels of several targets were elevated (Table 1), in agreement with previous studies, ${ }^{43}$ suggesting that PLX5622 actions are not mediated by a general reduction of the overall inflammatory response.

\section{Discussion}

Accumulation of microglia/macrophages in the subretinal space of CNV lesions and expression of inflammatory cytokines have both been implicated in the formation of CNV. ${ }^{10,12,44,45}$ However, the role of microglia/macrophages in $\mathrm{CNV}$ development is not clear yet because contradictory 
roles of these cells have been reported. Previous studies have shown that macrophage depletion can lead to a reduction of vascular endothelial growth factor (VEGF) production and CNV lesion size in mice, ${ }^{13,14}$ whereas other studies reported that lack of the CCR2 receptor and its ligand chemokine (C-C motif) ligand 2 in mice leads to spontaneous CNV development after 9 months of age. ${ }^{2}$ Moreover, microglia accumulation has been observed in AMD lesions in chemokine (C-C motif) ligand 2/CX3C chemokine receptor 1 -deficient mice but not in control mice, ${ }^{46}$ whereas several additional studies reported that resident microglia actively contribute to CNV development. ${ }^{12,47,48}$ Microglia/macrophage involvement in CNV is further supported by studies showing that reduction of microglia and macrophage reactivity by polysialic acid or translocator protein $18-\mathrm{kDa}$ ligands leads to reduced neurodegeneration and less vascular leakage in a CNV mouse model. ${ }^{17,49,50}$

Herein, we show that CSF-1R inhibition with PLX5622 leads to faster involution of $\mathrm{CNV}$, as revealed by in vivo imaging and immunohistochemical studies in retinal and choroid-RPE whole mounts (Figures 1 and 2). PLX5622 efficiently depletes retinal microglia as early as 1 week of treatment (Figures $1-3$ ). The flow cytometry data showed that PLX5622 reduced the total number of $\mathrm{CD} 45^{\mathrm{hi}} \mathrm{CD} 11 \mathrm{~b}^{+}$ cells in the retina, most probably representing invading monocyte-derived macrophages and perivascular macrophages, and largely prevented major histocompatibility complex class-II expression by microglia and $\mathrm{CD} 45^{\mathrm{hi}} \mathrm{CD} 11 \mathrm{~b}^{+}$cells (Figure $3 \mathrm{C}$ ). The effect of PLX5622 was not observed on CSF-1R expression by microglia or macrophages (Figure 3C). Recent studies by Paschalis et $\mathrm{al}^{32}$ suggested that ocular injury could trigger infiltration of peripheral monocytes into the retina, where they adopt a ramified morphology, similar to resting microglia, and express low levels of CSF-1R. ${ }^{51}$ However, this was not observed in the present study.

Flow cytometry analysis was also performed in the choroid-RPE complex of CNV-subjected mice fed with control or PLX5622 chow. These data revealed increased numbers of $\mathrm{CD} 11 \mathrm{c}^{+}$cells, leukocytes, and neutrophils after CNV (Figure 4), which is in agreement with previous studies. ${ }^{52,53} \mathrm{CD} 11 \mathrm{c}^{+}$dendritic cells have been previously reported to play a role in CNV development. Specifically, they have been found to accumulate in the CNV lesions, peaking in numbers between day 2 and 4 after laser-induced $\mathrm{CNV}$ in mice. ${ }^{53}$ Moreover, i.v. injection of dendritic cells leads to their accumulation into the CNV lesions, where they are associated with increased $\mathrm{CNV}$ size. ${ }^{53}$ Our data are consistent with these findings. Moreover, inhibition of the CSF-1R with PLX5622 did not only deplete retinal microglia, but it also affected the number of $\mathrm{CD} 11 \mathrm{c}^{+}$cells and leukocytes found in the choroid-RPE by reducing their numbers below naïve levels; it did not have any effect on neutrophil numbers (Figure 4A). Previous studies have shown that CSF-1R signaling is vital for dendritic cell differentiation, and dendritic cells are diminished in the spleen and peritoneum of CSF-1R-deficient mice. ${ }^{54}$ Moreover, Csflr depletion has been recently shown to negatively regulate the dendritic cell pool size in adult mice. ${ }^{55}$

Further analysis of leukocyte subsets showed an increase of inflammatory classic monocytes/macrophages $\left(\mathrm{Ly} \mathrm{G}^{\text {neg }} /\right.$ Ly6Chi 3 days after CNV, which was prevented by PLX5622. However, the population of patrolling nonclassic monocytes/ macrophages in the choroid-RPE, identified as Ly $6 \mathrm{G}^{\text {neg/ }}$ Ly6C $\mathrm{C}^{\text {low/neg }} / \mathrm{SSC}-\mathrm{H}^{\text {low }}$, was not affected by laser-induced CNV, but PLX5622 reduced their number below naïve levels, whereas the remaining cells were still positive for CSF1R expression (Figure 4B). This suggests that PLX5622 leads to a reduction of resident choroidal macrophage numbers and prevents the recruitment of Ly6 $\mathrm{C}^{\text {hi }}$ inflammatory monocytes/ macrophages into the affected area. Indeed, by using neutralizing antibodies against CSF-1R or its ligand CSF-1, it has been previously shown that blocking of CSF-1R signaling can lead to depletion of Ly $6 \mathrm{C}^{\text {neg }}$ monocytes in the blood, whereas it only has modest effects in Ly6 $\mathrm{C}^{+}$monocytes in the bone marrow. ${ }^{56-58}$ Thus, the beneficial effects of PLX5622 may be attributed at least partially to the reduced numbers of peripheral immune cells, which, along with retinal microglia, could contribute to the extracellular matrix remodeling that triggers the formation of new blood vessels.

To further investigate the effect of PLX5622 in the course of CNV, a panel of cytokines/chemokines was analyzed in CNV-subjected mice fed with PLX5622 or normal food, using a semiquantitative assay (the array membrane data are openly available in OSF Data repository-Open Science Framework at https://osf.io; reference number: $\mathrm{y} 5 \mathrm{n} 7 \mathrm{~h}$ ). Elevated levels of several cytokines/chemokines were found in the CNV-subjected eyes, whereas some of them were elevated even more in the presence of PLX5622 (Table 1). Among the highest up-regulated cytokines were CX3CL1, MMP-2, basic fibroblast growth factor, and VCAM-1, whereas others, such as IL-6, TNF- $\alpha$, and monocyte chemoattractant protein 1 (MCP-1), were not changed compared with naïve mice. CX3CL1 signaling is a key modulator of macrophage recruitment into the injured tissues, ${ }^{59,60}$ and it has been shown to reduce microglial activation and subsequent neurotoxicity. ${ }^{61,62}$ MMP-2, on the other hand, has been reported to play a prominent role in $\mathrm{CNV}$ formation because reduced CNV is observed in mice deficient for MMP-2. ${ }^{63-65}$ MMPs can proteolytically cleave several chemokines, leading to their inactivation or the generation of antagonistic derivatives, which cannot promote chemotaxis. ${ }^{66}$

No differences were detected in the levels of vascular endothelial growth factor (VEGF) between the experimental groups 3 and 7 days after CNV induction. VEGF is considered the major proangiogenic factor in the inflamed retina, ${ }^{67-69}$ and it has been suggested that interaction between VEGF and other proangiogenic factors, such as basic fibroblast growth factor, is required for the angiogenic actions of VEGF. ${ }^{70}$ Herein, an up-regulation of basic 
fibroblast growth factor was observed in the presence or absence of PLX5622, but no differences were observed in VEGF protein levels between naïve and CNV mice in the presence or absence of PLX5622. Most likely, these differences could be observed in earlier time points after the $\mathrm{CNV}$ induction.

In the presence of PLX5622, the proinflammatory IL-1 $\alpha$ was also elevated at day 3 after CNV laser induction and it was significantly reduced at day 7 . Up-regulation of the adhesion molecule VCAM-1 was also observed in our study, and this up-regulation was greater in the presence of PLX5622. VCAM-1 mediates the adhesion of monocytederived macrophages to vascular endothelial cells, and increased protein levels of VCAM-1 have been reported in the retinal vasculature during $\mathrm{CNV}$ in mice. ${ }^{11}$ However, increased infiltration of monocyte-derived macrophages into the injured retina was not observed in the presence of PLX5622.

In addition, significantly elevated levels of soluble TNFRI were found during the disease course of CNV in the presence of PLX5622. After TNF- $\alpha$ binds to its membrane receptors, TNFRI and TNFRII, the receptors are cleaved to their soluble forms (soluble TNFRI/soluble TNFRII) by metalloproteinases. ${ }^{71}$ The level of surface expression of TNFRI and its soluble form was found to be an important factor in regulating TNF- $\alpha$-mediated effects, ${ }^{72,73}$ and the receptor cleavage acts as an important mechanism for the suppression of TNF- $\alpha-$-mediated inflammation. ${ }^{74}$ The levels of the anti-inflammatory cytokines IL- 4 and IL-10 were also elevated in the PLX5622 group, and this was accompanied by down-regulation of interferon- $\gamma$ levels. Indeed, IL-10 has been previously reported to inhibit the production of interferon- $\gamma^{75}$ and to mediate a suppressive effect on CNV development. ${ }^{76}$ In addition, IL-4 has been shown to antagonize interferon- $\gamma$-induced activities in macrophages. ${ }^{77-79}$ The expression of IGFBP-3, IGFBP-5, and IGFBP-6 was also increased in the presence of PLX5622. IGFBPs bind with high activity to IGF and thus limit the free form of IGF in the circulation, ${ }^{80-82}$ thereby acting as angiogenesis suppressors. ${ }^{83-85}$ In keeping with this, IGF signaling has been proposed to play a role in diabetic retinopathy and retinal neovascularization, where it has been shown to lead to increased VEGF levels. ${ }^{86-88}$

Because of complex cytokine interactions that may act antagonistically, the apparent increase of the inflammatory cytokines after PLX5622, which is in keeping with previously published studies, ${ }^{43}$ may ultimately lead to a more angiostatic/antiangiogenic phenotype and thus inhibit CNV progression. In addition, it has been previously reported that CSF-1 can increase the release of VEGF from monocytes and CSF-1R inhibition can lead to lower levels of VEGF. ${ }^{89,90}$ Thus, blockade of the receptor may affect the angiogenesis mediated by CSF-1R-expressing cells. Moreover, physical contact between immune cells, such as perivascular macrophages, and endothelial cells may be required for the progression of CNV. In vitro studies have shown that direct contact between monocytes and endothelial cells can increase endothelial cell proliferation. ${ }^{48,91,92}$ Hence, reduction of retinal microglia and attenuation of perivascular macrophages could result in decreased endothelial cell proliferation and, therefore, regression of $\mathrm{CNV}$ lesions.

Our data are in agreement with previous studies that have shown elevation of cytokine and chemokine levels in the retinas of $\mathrm{CNV}$-subjected mice, as well as infiltration of monocyte-derived macrophages into the retina early during the course of $\mathrm{CNV} \cdot{ }^{11,93-95}$ Apart from microglia and monocyte-derived macrophages, RPE cells and vascular endothelial cells are also known to produce cytokines during $\mathrm{CNV}$ in mice. ${ }^{96}$ Moreover, activated Müller cells could also be a source of cytokines during CNV. On the basis of the PLX5622 depletion data, immune cells are likely not the main producers of cytokines during the course of our CNV model, yet they play an important role in CNV progression.

In summary, the present study highlights the important role of innate immunity in the course of CNV in mice. Inhibition of the CSF-1R has beneficial effects against CNV progression, but whether these effects are mediated by depletion of microglia and/or macrophages in the retina, by patrolling monocytes in the choroid, or by the prevention of leukocyte influx needs to be further investigated. In addition, a more detailed analysis of the cytokine and chemokine levels after PLX5622 treatment could provide valuable data toward specific biological effects of PLX5622 in retinal pathology.

\section{Acknowledgments}

We thank the Department for BioMedical Research (University of Bern) for use of facilities and scientific and technical assistance.

\section{Author Contributions}

P.S. designed and performed the experiments, analyzed and interpreted the data, and revised the manuscript; D.K. designed and performed the experiments, analyzed and interpreted the data, and wrote and revised the manuscript; A.E. contributed to the study design and revised the manuscript; M.S.Z. conceived and designed the experiments, interpreted the data, wrote and revised the manuscript, and supervised the project; all authors read and approved the final manuscript.

\section{Supplemental Data}

Supplemental material for this article can be found at https://doi.org/10.1016/j.ajpath.2019.10.011. 


\section{References}

1. Friedman DS, O'Colmain BJ, Munoz B, Tomany SC, McCarty C, de Jong PT, Nemesure B, Mitchell P, Kempen J; Eye Diseases Prevalence Research Group: Prevalence of age-related macular degeneration in the United States. Arch Ophthalmol 2004, 122:564-572

2. Ambati J, Ambati BK, Yoo SH, Ianchulev S, Adamis AP: Agerelated macular degeneration: etiology, pathogenesis, and therapeutic strategies. Surv Ophthalmol 2003, 48:257-293

3. Shaw PX, Stiles T, Douglas C, Ho D, Fan W, Du H, Xiao X: Oxidative stress, innate immunity, and age-related macular degeneration. AIMS Mol Sci 2016, 3:196-221

4. Kaarniranta K, Salminen A: Age-related macular degeneration: activation of innate immunity system via pattern recognition receptors. J Mol Med 2009, 87:117-123

5. Coughlin B, Schnabolk G, Joseph K, Raikwar H, Kunchithapautham K, Johnson K, Moore K, Wang Y, Rohrer B: Connecting the innate and adaptive immune responses in mouse choroidal neovascularization via the anaphylatoxin C5a and gammadeltaT-cells. Sci Rep 2016, 6:23794

6. Lee JE, Liang KJ, Fariss RN, Wong WT: Ex vivo dynamic imaging of retinal microglia using time-lapse confocal microscopy. Invest Ophthalmol Vis Sci 2008, 49:4169-4176

7. Hanisch UK, Kettenmann H: Microglia: active sensor and versatile effector cells in the normal and pathologic brain. Nat Neurosci 2007, 10:1387-1394

8. Killingsworth MC, Sarks JP, Sarks SH: Macrophages related to Bruch's membrane in age-related macular degeneration. Eye 1990, 4: 613-621

9. Penfold P, Killingsworth M, Sarks S: An ultrastructural study of the role of leucocytes and fibroblasts in the breakdown of Bruch's membrane. Aust J Ophthalmol 1984, 12:23-31

10. Yang Y, Liu F, Tang M, Yuan M, Hu A, Zhan Z, Li Z, Li J, Ding X, Lu L: Macrophage polarization in experimental and clinical choroidal neovascularization. Sci Rep 2016, 6:30933

11. Caicedo A, Espinosa-Heidmann DG, Pina Y, Hernandez EP, Cousins SW: Blood-derived macrophages infiltrate the retina and activate Muller glial cells under experimental choroidal neovascularization. Exp Eye Res 2005, 81:38-47

12. Combadiere C, Feumi C, Raoul W, Keller N, Rodero M, Pezard A, Lavalette S, Houssier M, Jonet L, Picard E, Debre P, Sirinyan M, Deterre P, Ferroukhi T, Cohen SY, Chauvaud D, Jeanny JC, Chemtob S, Behar-Cohen F, Sennlaub F: CX3CR1-dependent subretinal microglia cell accumulation is associated with cardinal features of age-related macular degeneration. J Clin Invest 2007, 117:2920-2928

13. Sakurai E, Anand A, Ambati BK, van Rooijen N, Ambati J: Macrophage depletion inhibits experimental choroidal neovascularization. Invest Ophthalmol Vis Sci 2003, 44:3578-3585

14. Espinosa-Heidmann DG, Suner IJ, Hernandez EP, Monroy D, Csaky KG, Cousins SW: Macrophage depletion diminishes lesion size and severity in experimental choroidal neovascularization. Invest Ophthalmol Vis Sci 2003, 44:3586-3592

15. Tsutsumi C, Sonoda KH, Egashira K, Qiao H, Hisatomi T, Nakao S, Ishibashi M, Charo IF, Sakamoto T, Murata T, Ishibashi T: The critical role of ocular-infiltrating macrophages in the development of choroidal neovascularization. J Leukoc Biol 2003, 74:25-32

16. Falk MK, Singh A, Faber C, Nissen MH, Hviid T, Sorensen TL: CX3CL1/CX3CR1 and CCL2/CCR2 chemokine/chemokine receptor complex in patients with AMD. PLoS One 2014, 9:e112473

17. Karlstetter M, Kopatz J, Aslanidis A, Shahraz A, Caramoy A, Linnartz-Gerlach B, Lin Y, Luckoff A, Fauser S, Duker K, Claude J, Wang Y, Ackermann J, Schmidt T, Hornung V, Skerka C, Langmann T, Neumann H: Polysialic acid blocks mononuclear phagocyte reactivity, inhibits complement activation, and protects from vascular damage in the retina. EMBO Mol Med 2017, 9: $154-166$
18. Langmann T, Fauser S: [Polysialic acid for immunomodulation in an animal model for wet age-related macular degeneration (AMD)] German. Klin Monbl Augenheilkd 2017, 234:657-661

19. Luckoff A, Caramoy A, Scholz R, Prinz M, Kalinke U, Langmann T: Interferon-beta signaling in retinal mononuclear phagocytes attenuates pathological neovascularization. EMBO Mol Med 2016, 8 : 670-678

20. Ma W, Silverman SM, Zhao L, Villasmil R, Campos MM, Amaral J, Wong WT: Absence of TGFbeta signaling in retinal microglia induces retinal degeneration and exacerbates choroidal neovascularization. Elife 2019, 8:e42049

21. Spangenberg EE, Lee RJ, Najafi AR, Rice RA, Elmore MR, BlurtonJones M, West BL, Green KN: Eliminating microglia in Alzheimer's mice prevents neuronal loss without modulating amyloid-beta pathology. Brain 2016, 139:1265-1281

22. Szalay G, Martinecz B, Lenart N, Kornyei Z, Orsolits B, Judak L, Csaszar E, Fekete R, West BL, Katona G, Rozsa B, Denes A: Microglia protect against brain injury and their selective elimination dysregulates neuronal network activity after stroke. Nat Commun 2016, 7:11499

23. Elmore MR, Najafi AR, Koike MA, Dagher NN, Spangenberg EE, Rice RA, Kitazawa M, Matusow B, Nguyen H, West BL, Green KN: Colony-stimulating factor 1 receptor signaling is necessary for microglia viability, unmasking a microglia progenitor cell in the adult brain. Neuron 2014, 82:380-397

24. Elmore MR, Lee RJ, West BL, Green KN: Characterizing newly repopulated microglia in the adult mouse: impacts on animal behavior, cell morphology, and neuroinflammation. PLoS One 2015, 10:e122912

25. Kokona D, Ebneter A, Escher P, Zinkernagel MS: Colony-stimulating factor 1 receptor inhibition prevents disruption of the blood-retina barrier during chronic inflammation. J Neuroinflammation 2018, 15:340

26. Ebneter A, Kokona D, Jovanovic J, Zinkernagel MS: Dramatic effect of oral CSF-1R kinase inhibitor on retinal microglia revealed by in vivo scanning laser ophthalmoscopy. Transl Vis Sci Technol 2017, 6:10

27. Bellver-Landete V, Bretheau F, Mailhot B, Vallieres N, Lessard M, Janelle ME, Vernoux N, Tremblay ME, Fuehrmann T, Shoichet MS, Lacroix S: Microglia are an essential component of the neuroprotective scar that forms after spinal cord injury. Nat Commun 2019, 10:518

28. Wheeler DL, Sariol A, Meyerholz DK, Perlman S: Microglia are required for protection against lethal coronavirus encephalitis in mice. J Clin Invest 2018, 128:931-943

29. Funk KE, Klein RS: CSF1R antagonism limits local restimulation of antiviral CD8(+) $\mathrm{T}$ cells during viral encephalitis. J Neuroinflammation 2019, 16:22

30. Zhang Y, Zhao L, Wang X, Ma W, Lazere A, Qian HH, Zhang J, Abu-Asab M, Fariss RN, Roger JE, Wong WT: Repopulating retinal microglia restore endogenous organization and function under CX3CL1-CX3CR1 regulation. Sci Adv 2018, 4:eaap8492

31. Huang Y, Xu Z, Xiong S, Qin G, Sun F, Yang J, Yuan TF, Zhao L, Wang K, Liang YX, Fu L, Wu T, So KF, Rao Y, Peng B: Dual extraretinal origins of microglia in the model of retinal microglia repopulation. Cell Discov 2018, 4:9

32. Paschalis EI, Lei F, Zhou C, Kapoulea V, Dana R, Chodosh J, Vavvas DG, Dohlman CH: Permanent neuroglial remodeling of the retina following infiltration of CSF1R inhibition-resistant peripheral monocytes. Proc Natl Acad Sci U S A 2018, 115:E11359-E11368

33. Zhu Y, Lu Q, Shen J, Zhang L, Gao Y, Shen X, Xie B: Improvement and optimization of standards for a preclinical animal test model of laser induced choroidal neovascularization. PLoS One 2014, 9:e94743

34. Sasmono RT, Oceandy D, Pollard JW, Tong W, Pavli P, Wainwright BJ, Ostrowski MC, Himes SR, Hume DA: A macrophage colony-stimulating factor receptor-green fluorescent protein transgene is expressed throughout the mononuclear phagocyte system of the mouse. Blood 2003, 101:1155-1163 
35. Kokona D, Schneider N, Giannakaki-Zimmermann H, Jovanovic J, Ebneter A, Zinkernagel M: Noninvasive quantification of retinal microglia using widefield autofluorescence imaging. Invest Ophthalmol Vis Sci 2017, 58:2160-2165

36. Ebneter A, Kokona D, Schneider N, Zinkernagel MS: Microglia activation and recruitment of circulating macrophages during ischemic experimental branch retinal vein occlusion. Invest Ophthalmol Vis Sci 2017, 58:944-953

37. Schneider CA, Rasband WS, Eliceiri KW: NIH Image to ImageJ: 25 years of image analysis. Nat Methods 2012, 9:671-675

38. Faul F, Erdfelder E, Lang AG, Buchner A: G*Power 3: a flexible statistical power analysis program for the social, behavioral, and biomedical sciences. Behav Res Methods 2007, 39:175-191

39. Ford AL, Goodsall AL, Hickey WF, Sedgwick JD: Normal adult ramified microglia separated from other central nervous system macrophages by flow cytometric sorting: phenotypic differences defined and direct ex vivo antigen presentation to myelin basic protein-reactive CD4+ T cells compared. J Immunol 1995, 154: 4309-4321

40. Liyanage SE, Gardner PJ, Ribeiro J, Cristante E, Sampson RD, Luhmann UF, Ali RR, Bainbridge JW: Flow cytometric analysis of inflammatory and resident myeloid populations in mouse ocular inflammatory models. Exp Eye Res 2016, 151:160-170

41. Patel BV, Tatham KC, Wilson MR, O'Dea KP, Takata M: In vivo compartmental analysis of leukocytes in mouse lungs. Am J Physiol Lung Cell Mol Physiol 2015, 309:L639-L652

42. Geissmann F, Manz MG, Jung S, Sieweke MH, Merad M, Ley K: Development of monocytes, macrophages, and dendritic cells. Science 2010, 327:656-661

43. Paschalis EI, Lei F, Zhou C, Chen XN, Kapoulea V, Hui PC, Dana R, Chodosh J, Vavvas DG, Dohlman CH: Microglia regulate neuroglia remodeling in various ocular and retinal injuries. J Immunol 2019, 202:539-549

44. Miao H, Tao Y, Li XX: Inflammatory cytokines in aqueous humor of patients with choroidal neovascularization. Mol Vis 2012, 18: $574-580$

45. Yamamoto Y, Miyazaki D, Sasaki S, Miyake K, Kaneda S, Ikeda Y, Baba T, Yamasaki A, Noguchi Y, Inoue Y: Associations of inflammatory cytokines with choroidal neovascularization in highly myopic eyes. Retina 2015, 35:344-350

46. Tuo J, Bojanowski CM, Zhou M, Shen D, Ross RJ, Rosenberg KI, Cameron DJ, Yin C, Kowalak JA, Zhuang Z, Zhang K, Chan CC: Murine $\mathrm{ccl} 2 / \mathrm{cx} 3 \mathrm{cr} 1$ deficiency results in retinal lesions mimicking human age-related macular degeneration. Invest Ophthalmol Vis Sci 2007, 48:3827-3836

47. Ma W, Zhao L, Fontainhas AM, Fariss RN, Wong WT: Microglia in the mouse retina alter the structure and function of retinal pigmented epithelial cells: a potential cellular interaction relevant to AMD. PLoS One 2009, 4:e7945

48. Rymo SF, Gerhardt H, Wolfhagen Sand F, Lang R, Uv A, Betsholtz C: A two-way communication between microglial cells and angiogenic sprouts regulates angiogenesis in aortic ring cultures. PLoS One 2011, 6:e15846

49. Scholz R, Caramoy A, Bhuckory MB, Rashid K, Chen M, Xu H, Grimm C, Langmann T: Targeting translocator protein $(18 \mathrm{kDa})$ (TSPO) dampens pro-inflammatory microglia reactivity in the retina and protects from degeneration. J Neuroinflammation 2015, 12:201

50. Rashid K, Wolf A, Langmann T: Microglia activation and immunomodulatory therapies for retinal degenerations. Front Cell Neurosci 2018, 12:176

51. Paschalis EI, Lei F, Zhou C, Kapoulea V, Thanos A, Dana R, Vavvas DG, Chodosh J, Dohlman CH: The role of microglia and peripheral monocytes in retinal damage after corneal chemical injury. Am J Pathol 2018, 188:1580-1596

52. Lavalette S, Raoul W, Houssier M, Camelo S, Levy O, Calippe B, Jonet L, Behar-Cohen F, Chemtob S, Guillonneau X, Combadiere C, Sennlaub F: Interleukin-1beta inhibition prevents choroidal neovascularization and does not exacerbate photoreceptor degeneration. Am J Pathol 2011, 178: $2416-2423$

53. Nakai K, Fainaru O, Bazinet L, Pakneshan P, Benny O, Pravda E, Folkman J, D'Amato RJ: Dendritic cells augment choroidal neovascularization. Invest Ophthalmol Vis Sci 2008, 49:3666-3670

54. MacDonald KP, Rowe V, Bofinger HM, Thomas R, Sasmono T, Hume DA, Hill GR: The colony-stimulating factor 1 receptor is expressed on dendritic cells during differentiation and regulates their expansion. J Immunol 2005, 175:1399-1405

55. Percin GI, Eitler J, Kranz A, Fu J, Pollard JW, Naumann R, Waskow C: CSF1R regulates the dendritic cell pool size in adult mice via embryo-derived tissue-resident macrophages. Nat Commun 2018, 9:5279

56. Hashimoto D, Chow A, Greter M, Saenger Y, Kwan WH, Leboeuf M, Ginhoux F, Ochando JC, Kunisaki Y, van Rooijen N, Liu C, Teshima T, Heeger PS, Stanley ER, Frenette PS, Merad M: Pretransplant CSF-1 therapy expands recipient macrophages and ameliorates GVHD after allogeneic hematopoietic cell transplantation. J Exp Med 2011, 208:1069-1082

57. Lenzo JC, Turner AL, Cook AD, Vlahos R, Anderson GP, Reynolds EC, Hamilton JA: Control of macrophage lineage populations by CSF-1 receptor and GM-CSF in homeostasis and inflammation. Immunol Cell Biol 2012, 90:429-440

58. Louis C, Cook AD, Lacey D, Fleetwood AJ, Vlahos R, Anderson GP, Hamilton JA: Specific contributions of CSF-1 and GM-CSF to the dynamics of the mononuclear phagocyte system. J Immunol 2015, 195:134-144

59. Combadiere C, Potteaux S, Rodero M, Simon T, Pezard A, Esposito B, Merval R, Proudfoot A, Tedgui A, Mallat Z: Combined inhibition of CCL2, CX3CR1, and CCR5 abrogates Ly6C(hi) and Ly6C(lo) monocytosis and almost abolishes atherosclerosis in hypercholesterolemic mice. Circulation 2008, 117:1649-1657

60. Combadiere C, Potteaux S, Gao JL, Esposito B, Casanova S, Lee EJ, Debre P, Tedgui A, Murphy PM, Mallat Z: Decreased atherosclerotic lesion formation in CX3CR1/apolipoprotein E double knockout mice. Circulation 2003, 107:1009-1016

61. Pabon MM, Bachstetter AD, Hudson CE, Gemma C, Bickford PC: CX3CL1 reduces neurotoxicity and microglial activation in a rat model of Parkinson's disease. J Neuroinflammation 2011, 8:9

62. Mizuno T, Kawanokuchi J, Numata K, Suzumura A: Production and neuroprotective functions of fractalkine in the central nervous system. Brain Res 2003, 979:65-70

63. Berglin L, Sarman S, van der Ploeg I, Steen B, Ming Y, Itohara S, Seregard S, Kvanta A: Reduced choroidal neovascular membrane formation in matrix metalloproteinase-2-deficient mice. Invest Ophthalmol Vis Sci 2003, 44:403-408

64. Ohno-Matsui K, Uetama T, Yoshida T, Hayano M, Itoh T, Morita I, Mochizuki M: Reduced retinal angiogenesis in MMP-2-deficient mice. Invest Ophthalmol Vis Sci 2003, 44:5370-5375

65. Cai J, Yin G, Lin B, Wang X, Liu X, Chen X, Yan D, Shan G, Qu J, Wu S: Roles of NFkappaB-miR-29s-MMP-2 circuitry in experimental choroidal neovascularization. J Neuroinflammation 2014, 11:88

66. Van Lint $\mathrm{P}$, Libert $\mathrm{C}$ : Chemokine and cytokine processing by matrix metalloproteinases and its effect on leukocyte migration and inflammation. J Leukoc Biol 2007, 82:1375-1381

67. Vinores SA, Xiao WH, Aslam S, Shen J, Oshima Y, Nambu H, Liu H, Carmeliet P, Campochiaro PA: Implication of the hypoxia response element of the Vegf promoter in mouse models of retinal and choroidal neovascularization, but not retinal vascular development. J Cell Physiol 2006, 206:749-758

68. Aiello LP, Pierce EA, Foley ED, Takagi H, Chen H, Riddle L, Ferrara N, King GL, Smith LE: Suppression of retinal neovascularization in vivo by inhibition of vascular endothelial growth factor (VEGF) using soluble VEGF-receptor chimeric proteins. Proc Natl Acad Sci U S A 1995, 92:10457-10461 
69. Okamoto N, Tobe T, Hackett SF, Ozaki H, Vinores MA, LaRochelle W, Zack DJ, Campochiaro PA: Transgenic mice with increased expression of vascular endothelial growth factor in the retina: a new model of intraretinal and subretinal neovascularization. Am J Pathol 1997, 151:281-291

70. Kwak N, Okamoto N, Wood JM, Campochiaro PA: VEGF is major stimulator in model of choroidal neovascularization. Invest Ophthalmol Vis Sci 2000, 41:3158-3164

71. Aderka D: The potential biological and clinical significance of the soluble tumor necrosis factor receptors. Cytokine Growth Factor Rev 1996, 7:231-240

72. Fessler SP, Chin YR, Horwitz MS: Inhibition of tumor necrosis factor (TNF) signal transduction by the adenovirus group C RID complex involves downregulation of surface levels of TNF receptor 1. J Virol 2004, 78:13113-13121

73. Cook EB, Stahl JL, Graziano FM, Barney NP: Regulation of the receptor for TNFalpha, TNFR1, in human conjunctival epithelial cells. Invest Ophthalmol Vis Sci 2008, 49:3992-3998

74. Xanthoulea S, Pasparakis M, Kousteni S, Brakebusch C, Wallach D, Bauer J, Lassmann H, Kollias G: Tumor necrosis factor (TNF) receptor shedding controls thresholds of innate immune activation that balance opposing TNF functions in infectious and inflammatory diseases. J Exp Med 2004, 200:367-376

75. D'Andrea A, Aste-Amezaga M, Valiante NM, Ma X, Kubin M, Trinchieri G: Interleukin 10 (IL-10) inhibits human lymphocyte interferon gamma-production by suppressing natural killer cell stimulatory factor/IL-12 synthesis in accessory cells. J Exp Med 1993, 178:1041-1048

76. Matsumura N, Kamei M, Tsujikawa M, Suzuki M, Xie P, Nishida K: Low-dose lipopolysaccharide pretreatment suppresses choroidal neovascularization via IL-10 induction. PLoS One 2012, 7:e39890

77. te Velde AA, Huijbens RJ, Heije K, de Vries JE, Figdor CG: Interleukin-4 (IL-4) inhibits secretion of IL-1 beta, tumor necrosis factor alpha, and IL-6 by human monocytes. Blood 1990, 76: 1392-1397

78. Mijatovic T, Kruys V, Caput D, Defrance P, Huez G: Interleukin-4 and -13 inhibit tumor necrosis factor-alpha mRNA translational activation in lipopolysaccharide-induced mouse macrophages. J Biol Chem 1997, 272:14394-14398

79. Gautam S, Tebo JM, Hamilton TA: IL-4 suppresses cytokine gene expression induced by IFN-gamma and/or IL-2 in murine peritoneal macrophages. J Immunol 1992, 148:1725-1730

80. Frystyk J, Grofte T, Skjaerbaek C, Orskov H: The effect of oral glucose on serum free insulin-like growth factor-I and -II in health adults. J Clin Endocrinol Metab 1997, 82:3124-3127

81. Delafontaine P, Song YH, Li Y: Expression, regulation, and function of IGF-1, IGF-1R, and IGF-1 binding proteins in blood vessels. Arterioscler Thromb Vasc Biol 2004, 24:435-444

82. Bach LA: Recent insights into the actions of IGFBP-6. J Cell Commun Signal 2015, 9:189-200

83. Liu B, Lee KW, Anzo M, Zhang B, Zi X, Tao Y, Shiry L, Pollak M, Lin S, Cohen P: Insulin-like growth factor-binding protein-3 inhibition of prostate cancer growth involves suppression of angiogenesis. Oncogene 2007, 26:1811-1819

84. Rho SB, Dong SM, Kang S, Seo SS, Yoo CW, Lee DO, Woo JS, Park SY: Insulin-like growth factor-binding protein-5 (IGFBP-5) acts as a tumor suppressor by inhibiting angiogenesis. Carcinogenesis 2008, 29:2106-2111

85. Zhang C, Lu L, Li Y, Wang X, Zhou J, Liu Y, Fu P, Gallicchio MA, Bach LA, Duan C: IGF binding protein-6 expression in vascular endothelial cells is induced by hypoxia and plays a negative role in tumor angiogenesis. Int J Cancer 2012, 130:2003-2012

86. Kondo T, Vicent D, Suzuma K, Yanagisawa M, King GL, Holzenberger M, Kahn CR: Knockout of insulin and IGF-1 receptors on vascular endothelial cells protects against retinal neovascularization. J Clin Invest 2003, 111:1835-1842

87. Lu M, Amano S, Miyamoto K, Garland R, Keough K, Qin W, Adamis AP: Insulin-induced vascular endothelial growth factor expression in retina. Invest Ophthalmol Vis Sci 1999, 40:3281-3286

88. Poulaki V, Qin W, Joussen AM, Hurlbut P, Wiegand SJ, Rudge J, Yancopoulos GD, Adamis AP: Acute intensive insulin therapy exacerbates diabetic blood-retinal barrier breakdown via hypoxiainducible factor-1alpha and VEGF. J Clin Invest 2002, 109:805-815

89. Eubank TD, Galloway M, Montague CM, Waldman WJ, Marsh CB: M-CSF induces vascular endothelial growth factor production and angiogenic activity from human monocytes. J Immunol 2003, 171: 2637-2643

90. Priceman SJ, Sung JL, Shaposhnik Z, Burton JB, Torres-Collado AX, Moughon DL, Johnson M, Lusis AJ, Cohen DA, Iruela-Arispe ML, Wu L: Targeting distinct tumor-infiltrating myeloid cells by inhibiting CSF-1 receptor: combating tumor evasion of antiangiogenic therapy. Blood 2010, 115:1461-1471

91. Schubert SY, Benarroch A, Ostvang J, Edelman ER: Regulation of endothelial cell proliferation by primary monocytes. Arterioscler Thromb Vasc Biol 2008, 28:97-104

92. Arnold T, Betsholtz C: The importance of microglia in the development of the vasculature in the central nervous system. Vasc Cell 2013, 5:4

93. Apte RS, Richter J, Herndon J, Ferguson TA: Macrophages inhibit neovascularization in a murine model of age-related macular degeneration. PLoS Med 2006, 3:e310

94. Hasegawa E, Oshima Y, Takeda A, Saeki K, Yoshida H, Sonoda KH, Ishibashi T: IL-27 inhibits pathophysiological intraocular neovascularization due to laser burn. J Leukoc Biol 2012, 91:267-273

95. Liu J, Copland DA, Horie S, Wu WK, Chen M, Xu Y, Paul Morgan B, Mack M, Xu H, Nicholson LB, Dick AD: Myeloid cells expressing VEGF and arginase-1 following uptake of damaged retinal pigment epithelium suggests potential mechanism that drives the onset of choroidal angiogenesis in mice. PLoS One 2013, 8:e72935

96. Grossniklaus HE, Ling JX, Wallace TM, Dithmar S, Lawson DH, Cohen C, Elner VM, Elner SG, Sternberg P Jr: Macrophage and retinal pigment epithelium expression of angiogenic cytokines in choroidal neovascularization. Mol Vis 2002, 8:119-126 